\title{
Histopathological alterations in Senegal sole, Solea Senegalensis, from a polluted Huelva estuary (SW, Spain)
}

\author{
M. Oliva · J. J. Vicente-Martorell • \\ M. D. Galindo-Riaño $\cdot$ J. A. Perales
}

Received: 19 September 2011/ Accepted: 10 September 2012/Published online: 26 September 2012

(C) Springer Science+Business Media B.V. 2012

\begin{abstract}
As a component of a large research project to evaluate the effects of contaminants on fish health in the field, histopathological studies have been conducted to help establish causal relationship between pollutants (heavy metals and aromatic polycyclic hydrocarbonsPAHs) and histopathological responses in Senegal sole, Solea senegalensis, from an estuary of SW Spain. Heavy metals ( $\mathrm{As}, \mathrm{Zn}, \mathrm{Cd}, \mathrm{Pb}, \mathrm{Cu}$ and $\mathrm{Fe}$ ) and 16 PAHs (proprietary USEPA) concentrations in water, sediment and tissues (liver and gills) and histopathological alterations in S. senegalensis from three sampling sites of Ria de Huelva estuary during 2004-2006 years have been analysed. The histopathological studies revealed seasonal and spatial differences in the lesion grade of alterations
\end{abstract}

\section{Oliva ( $\bowtie)$}

Department of Biology, Faculty of Marine and Environmental Sciences, University of Cadiz, Campus de Excelencia Internacional del Mar (CEIMAR), Avda. República Saharaui S/N Puerto Real, 11510 Puerto Real, Cadiz, Spain

e-mail: milagrosa.oliva@uca.es

\section{J. J. Vicente-Martorell · M. D. Galindo-Riaño} Department of Analytical Chemistry, Faculty of Sciences, CEIMAR, University of Cadiz, 11510 Puerto Real, Cadiz, Spain

\section{J. A. Perales}

Department of Environmental Technologies, CACYTMAR, Andalusia Centre of Marine Sciences and Technology, Faculty of Marine and Environmental Sciences, CEIMAR, University of Cadiz, 11510 Puerto Real, Cadiz, Spain observing the highest lesion grades in fish from Odiel River and autumn season. No significant differences were observed in the alterations prevalence between sampling sites, but significant differences were observed between seasons observing the highest prevalence in autumn season. However, calculated IPAT demonstrated a lowmoderate impact of pollutants on health fish. Correlations between histopathological alterations and pollutants analysed were observed being heavy metals the group that presented a major number of correlations with alterations in several organs of $S$. senegalensis. In evaluating the general health of fish, the use of histopathological studies in recommended for making more reliable assessment of biochemical responses in fish exposed to a variety of environmental stressors. Statistical analysis using semiquantitative data on pathological lesions can help to establish correlation between cause (stressor) and effect (biomarker).

Keywords Histopathology $\cdot$ Sole $\cdot$ Metals · PAHs · Pathology index

\section{Introduction}

Industrial and agricultural sectors activity has increased the levels of heavy metals and polycyclic aromatic hydrocarbons (PAHs) in the aquatic environment through atmospheric fallout, dumping wastes, accidental leaks, run-off from terrestrial systems and 
by geological weathering. Estuarine environment is a major sink for potentially hazardous chemical.

Chemical monitoring programs are restricted to identification of a limited range of contaminants and provide no information on their biological significance. The biotic integrity of an ecological system is often reflected by the health of organisms that reside in that system. In aquatic ecosystem, fish are generally regarded as representative indicators of overall system health. Because of their position in the food chain, fish integrate the effects of many pollutants acting in the system and reflect secondary impacts of chronic stress. Factors such as temperature, high water and load sediment velocities, oxygen concentrations, food availability, anthropogenic stressors, etc. can impose considerable stress on physiological systems of fish and impair their health. Depending on its severity, stress can load or limit physiological systems, reduce growth, impair reproduction, predispose fish to disease and reduce the capacity of fish to tolerate additional stressors (Adams et al. 1993).

In recent years, increasing emphasis has been placed on the evaluation of the causal relationships between contaminant exposure and observable biological effects in aquatic organisms (De Flora et al. 1991). Fish pathologies are increasingly being used as indicators of environmental contamination since they provide a definite biological end-point of historical exposure (Matthiessen et al. 1993).

Several liver and gills lesions in marine fish have been shown to be associated with exposure to xenobiotic chemicals: neoplasms, non-neoplastic proliferative lesions and specific degenerative/necrotic lesions that are well established as histological biomarkers of response to contaminant exposure (Stehr et al. 1998; Adams et al. 2003).

Solea senegalensis is a benthonic marine species living in sandy or muddy bottoms, off coastal areas up to $100 \mathrm{~m}$ depth, in brackish lakes and estuaries. Senegal sole feeds basically on benthonic invertebrate, such as larvae from polychaets, bivalve molluscs and small crustaceans. Sexual maturity is reached when size is $30 \mathrm{~cm}$. Spawning happens between the months of March until June (Froese and Pauly 2010). Solea senegalensis is a well-adapted species to warm climates and is commonly exploited in extensive aquaculture production in Spain and Portugal (Drake et al. 1984; Dinis 1992; Sarasquete et al. 1998) and have been used in field and laboratory toxicity assays being a sensitive specie to pollutants (Jimenez-Tenorio et al. 2008; Oliva et al. 2009; Costa et al. 2009).

The present paper focuses on histopathological investigations that have been proved to be a sensitive tool to detect direct toxic effects of chemical compounds within target organs of fish in field investigation (The et al. 1997; Schwaiger et al. 1997; Stentiford et al. 2003; Au 2004; Costa et al. 2009). Histopathological responses were quantified using semiquantitative procedure to compare the severity of lesions in fish from different sampling sites.

This study reports histopathological alterations in an estuarine fish specie from southwest of Spain and study the possible correlation-ships between heavy metals and PAHs concentrations and alterations observed in liver and gills of S. senegalensis.

\section{Materials and methods}

Sampling sites

The Ría of Huelva is located on the southern Spanish Atlantic coast, where the Odiel (H1) and Tinto (H2) Rivers join to form the Padre Santo Canal (H3), which drains into the gulf of Cadiz forming a wide estuary (Fig. 1). The estuary receives contaminating inputs from a mining and industrial area in the estuary where is located an important petroleum refinery (Jimenez-Tenorio et al. 2007; Vicente Martorell et al. 2009). Four samplings were conducted from October

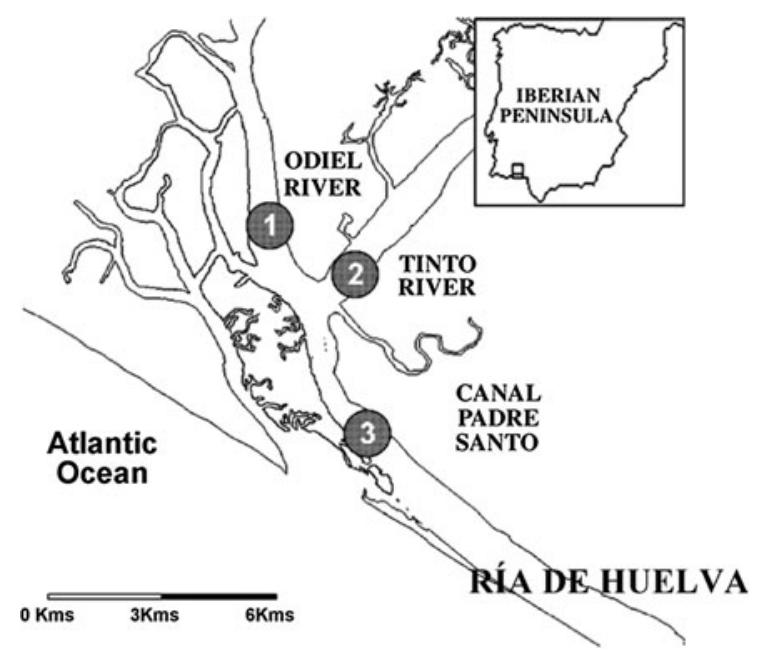

Fig. 1 Location map of sampling sites in Huelva (Spain): 1 (Odiel river); 2 (Tinto river); 3 (Padre Santo Canal) 
2004 to May 2006; two of them were realized at autumn (October 2004 and October 2005) and the others at spring (April 2005 and May 2006). During each sampling, sediment and fish samples of the three different sampling sites were obtained.

Fish collection

Specimens of Senegal sole $S$. senegalensis were collected at each sampling site for each sampling period and were transported in aerated tanks to Mazagon's port (Huelva). A total of 97 (125.04 $\pm 27.12 \mathrm{~g}$ of weight, $23.14 \pm 1.8 \mathrm{~cm}$ of length) fish were dissected, and samples of liver and gills of each fish were taken. Fish tissue samples were transported to the laboratory fixed in formalin. Due to all captured fish were in the juvenile life stage (that is sexually immature), gender data has not been considerate in this work. The specimens captured had a lower size than the reproductive size $(25-30 \mathrm{~cm})$, being probable to live around two-three years in the same zone. The experiments described comply with the Guidelines of the European Union Council (86/609/EU), the Spanish Government (RD 1201/2005) and the University of Cadiz (Spain) for the use of animals in research.

Heavy metals analysis in fish

Collected fishes were dissected, and tissue samples from liver, gills and muscle were taken. Freeze-dried samples of liver were acid digested by microwave heating using $\mathrm{HNO}_{3}$ and $\mathrm{H}_{2} \mathrm{O}_{2}$. Metal concentrations of digested tissue samples were analysed by ICP-MS and ICP-AES. The accuracy of methodology applied was satisfactorily evaluated using DOLT-3 (dogfish liver) certified reference materials.

Heavy metals analysis in sediments

Surface sediment samples $(2-20 \mathrm{~cm})$ were collected using a dredge and stored in polyethylene bags at $-4{ }^{\circ} \mathrm{C}$ until analysis. Fine particle-size fractions were obtained from the dried grinded and sieved sediments. The BCR sequential extraction (exchangeable, reducible, oxidizable and residue fraction) procedure was applied (Davidson et al. 1999), and speciation and total concentrations of metal were evaluated by using ICP-AES or AAS. NIST 1649a-certified reference estuarine sediment was used for analysis validation.
Two replicas of total metals analysis were made for each sample.

Heavy metals analysis in water

Water samples were obtained using a peristaltic bomb. To filter samples in situ, a $0.45-\mu \mathrm{m}$ Calyx Capsule MSI filter connected to the bomb was used. Total metal, particulate metal fraction and dissolved metal fractions (labile organic, labile inorganic, moderately labile inorganic, moderately labile organic and no labile dissolved metal) were analysed by stripping voltammetry after acid digestion. Dissolved metal speciation was carried out by metal fractionation to different $\mathrm{pH}$ distinguished among labile inorganic and organic metal, moderately labile inorganic and organic metal and inert fraction. In addition, particulate and organic and inorganic dissolved arsenic species were evaluated by using hydride generation and AAS, with an operational discrimination among fractions. Four replicas of metal analysis were made for each sample. Analytical methods were checked by using CRM 505 certified reference estuarine water.

\section{Analytical procedure for PAHs}

The 16 PAHs identified by United states Environmental Protection Agency (EPA) and World Health Organisation (WHO) as priority pollutants have been analysed in samples of sediment and hepatic tissue of $S$. sengalensis. The 16 PAHs (total PAHs-TPAHs) have been divided in two different categories: low-molecular-weight PAHs-LPAHs - (naphthalene, acenaphthylene, acenaphthene, fluorene, phenantherene, anthracene, fluoranthene and pyrene) and high-molecular-weight PAHs-HPAHs-(benzo(a)anthracene, chrysene, benzo(b)fluoranthene, benzo(k)fluoranthene, benzo(a)pyrene, dibenzo(a,h)anthracene, benzo(g,h,i)perylene, indeno (1,2,3-cd)pyrene).

PAH analysis in sediment was based on the analytical procedure proposed by the USEPA $(1996,2000)$. Approximately $2-4 \mathrm{~g}$ of sediment was weighed and treated with anhydrous $\mathrm{Na}_{2} \mathrm{SO}_{4}$. The samples were Soxhlet-extracted with $10 \mathrm{~mL}$ dichloromethaneacetone $(8: 2 \mathrm{v} / \mathrm{v})$ for $24 \mathrm{~h}$ (6 cycles per hour). The extracts were purified on florisil columns, and the PAHs were eluted with $100 \mathrm{~mL}$ dichloromethane-hexane $(2: 8 \mathrm{v} / \mathrm{v})$. The extract was concentrated to $1 \mathrm{~mL}$ using a 
rotary evaporator after changing the solvent from dichloromethane-hexane to acetonitrile. $\mathrm{Na}_{2} \mathrm{SO}_{4}$ was of analytical grade, and dichoromethane, hexane, acetone and acetonitrile were HPLC grade. Three replicas of PAHs analysis were made for each sample.

The composition and concentration of 16 different PAHs was determined by HPLC. A standard solution, SUPELCO 47940-u PAH mix in acetonitrile (containing 16 individual PAHs), was used for quantification.

\section{Analytical procedure for PAHs metabolites}

Post-mitochondrial supernatant (PMS) of liver and gills were further diluted in methanol $50 \%$ to $1: 400$ for FF measurement. Fluorescent readings were performed for naphthalene-type metabolites at excitation/ emission 290/335 nm; benzo(a)pyrene-type metabolites readings were made at $380 / 430 \mathrm{~nm}$; for pyrenetype metabolites, readings were made at $341 / 383$ and for phenanthrene-type metabolites, readings were made at 256/380. Gills cytosol metabolites are reported on the basis of milligram protein as previously adapted by Gagnon and Holdway (2000).

\section{Histopathological study}

The tissue samples for the histological exam were fixed in formalin (10\%), washed in running tap water, dehydrated in alcohol and acetone, cleared in xylene and embedded in paraffin wax. Sections $(6 \mu \mathrm{m})$ were cut and mounted on gelatinized slides using a rotary microtome. Sections were rehydrated in distilled water and stained with haematoxylin/eosin (H/E) and haematoxylin/VOF (H/V) (light green, orange-G and acid fuchsine) (Gutiérrez 1967). Pathology criteria were derived from several tissue alterations specified by the International Council for the Exploration of the Sea (ICES) and additional pathology observed in the sampled specimens. Histopathological sections were read after the course of each sampling period. Alterations were evaluated semiquantitatively by ranking the severity of the alteration in the tissue. Ranking was grade 0 (no alterations), grade 1 (focal mild alteration), grade 2 (moderate alteration) and grade 3 (extended severe alteration). This ranking was used to establish an overall assessment value of the histopathological lesions for each organ of individual fish.
No S. senegalensis specimen was captured from Canal de Padre Santo in spring seasons.

\section{IPAT (index of pathologies)}

IPAT is a modified index from histopathological condition index of Bernet et al. (1999). For each alteration, an importance factor or condition weight (w) was assigned, as proposed by Bernet and co-workers, based on the biological significance of the lesion, that is, the grade in which a lesion may affect the normal functioning of a tissue or organ.

The alterations are classified into three importance factors (condition weight):

1. Minimal pathological importance, the lesion is easily reversible as exposure to irritants ends.

2. Moderate pathological importance, the lesion is reversible in most cases if the stressor is neutralized.

3. Marked pathological importance, the lesion is generally irreversible, leading to partial or total loss of the organ function.

In this work, the prevalence of lesions has been also included in the index calculation because IPAT is not an organ pathological index but it is a general index on pathological state of fish from a specifically site and season. The index was obtained for each sampling site and season and was calculated by the simple formula:

$\mathrm{IPAT}=\sum_{i=1}^{n} \frac{a \lg _{i} \times p_{i} \times w_{i}}{100}$

where (alg) is the average lesion grade of the alteration, $(p)$ is the prevalence of this alteration, $(w)$ is the condition weight and $(n)$ is the number of pathologies analysed in each fish.

The maximum value that IPAT index can reach for each sampling and site is 54. For each site and sampling, IPAT was calculated to establish an assessment value varying through $1-54$. Assessment values $\leq 17$ were assumed to be a low impact, values between 18 and 36 were assumed to be a moderate impact and values $>36$ were assumed to be a high impact of health fish.

\section{Statistical analysis}

Statistical analyses were performed using the statistical software package STATISTICA (data analysis software system) version 7 (2004, Statsoft, Inc. USA). 
For each data set, the assumptions of an analysis of variance (ANOVA), normality and equal variance, were checked using Shapiro-Wilks and Levene tests, respectively. If the assumptions were not met, the necessary transformations were performed. If data set has normality, one-way ANOVA were conducted and where significant, a post hoc mean comparison test (Tukey's test) was realized. If non-normal data set was found, the Kruskal-Wallis and Man Whitney (one-tail) tests to find the significant differences were conducted.

To analyse the correlation between alterations and pollutants concentrations, Pearson and Spearman correlations test were used. All statistical analyses were conducted at an alpha level of 0.05 .

\section{Results}

Metal concentration in water

Metal concentrations of water samples from different sampling sites (mean values) are shown in Table 1.
Total metals were ranging over following intervals: $\mathrm{Zn}, \quad 49.8-381.6 \mu \mathrm{g} \mathrm{L}^{-1}$; $\mathrm{Cd}, 0.7-8.9 \mu \mathrm{g} \mathrm{L}^{-1} ; \mathrm{Pb}$, 2.6-17.8 $\mu \mathrm{g} \mathrm{L}^{-1}$; $\mathrm{Cu}, 20.9-72.4 \mu \mathrm{g} \mathrm{L}^{-1}$; and As, 2.6-9.3 $\mu \mathrm{g} \mathrm{L}^{-1}$.

Generally, content of metal in Tinto and Odiel sites was higher than content of metal in the Canal del Padre Santo site. Otherwise, slight higher mean values were found for $\mathrm{Zn}$ and $\mathrm{Cu}$ in Tinto water comparing with Odiel samples. Conversely, higher mean values were found for $\mathrm{Pb}$ in Odiel water. As and $\mathrm{Cd}$ showed similar mean concentrations in both sites.

The metal with the highest concentration was $\mathrm{Zn}$ and $\mathrm{Cu}$. They can be arranged as follows (higher content to lesser content): $\mathrm{Zn}>\mathrm{Cu}>\mathrm{Pb} \approx \mathrm{As}>\mathrm{Cd}$ and grouped depending on their behaviour in two sets: $\mathrm{Zn}-\mathrm{Cu}-\mathrm{Cd}$ and $\mathrm{Pb}-\mathrm{As}$. $\mathrm{Pb}$ and As average concentrations were similar in Tinto sampling site.

The scheme of metal speciation in water applied in this work allowed to perform a first fractionation between dissolved and particulate metal, considering the last fraction as less available. Data on distribution of metal speciation in water can be consulted in Vicente Martorell et al. (2009). Spatial variation was

Table 1 Mean values and standard deviation of metal and PAHs concentrations in water and sediments

\begin{tabular}{|c|c|c|c|c|c|c|}
\hline \multirow[t]{2}{*}{ Metals/PAHs } & \multicolumn{2}{|c|}{ Odiel river } & \multicolumn{2}{|l|}{ Tinto River } & \multicolumn{2}{|c|}{ Padre Santo Canal } \\
\hline & Mean & SD & Mean & SD & Mean & SD \\
\hline \multicolumn{7}{|l|}{ Water } \\
\hline $\mathrm{Zn}\left(\mu \mathrm{g} \mathrm{L}^{-1}\right)$ & 194.59 & 132.68 & 223.71 & 86.54 & 83.21 & 37.24 \\
\hline $\mathrm{Cd}\left(\mu \mathrm{g} \mathrm{L}^{-1}\right)$ & 3.73 & 3.55 & 3.70 & 2.49 & 0.99 & 0.45 \\
\hline $\mathrm{Pb}\left(\mu \mathrm{g} \mathrm{L}^{-1}\right)$ & 8.47 & 6.36 & 5.41 & 1.62 & 4.92 & 1.63 \\
\hline $\mathrm{Cu}\left(\mu \mathrm{g} \mathrm{L}^{-1}\right)$ & 50.80 & 10.91 & 56.19 & 16.81 & 32.16 & 17.30 \\
\hline As $\left(\mu \mathrm{g} \mathrm{L}^{-1}\right)$ & 5.23 & 2.78 & 5.45 & 1.86 & 3.70 & 1.66 \\
\hline \multicolumn{7}{|l|}{ Sediments } \\
\hline $\mathrm{Zn}$ (mg kg ${ }^{-1}$ dry weight) & 1153.71 & 483.31 & 1115.23 & 316.76 & 1430.67 & 118.38 \\
\hline $\mathrm{Cd}$ (mg kg ${ }^{-1}$ dry weight) & 14.43 & 13.70 & 8.42 & 6.59 & 7.09 & 5.58 \\
\hline $\mathrm{Pb}$ (mg kg ${ }^{-1}$ dry weight) & 589.91 & 487.50 & 495.95 & 326.17 & 630.03 & 379.75 \\
\hline $\mathrm{Cu}$ (mg kg ${ }^{-1}$ dry weight) & 2109.05 & 925.03 & 1897.18 & 496.72 & 2215.11 & 551.55 \\
\hline As (mg kg ${ }^{-1}$ dry weight) & 330.46 & 223.95 & 393.33 & 140.60 & 384.08 & 189.84 \\
\hline $\mathrm{Fe}\left(\mathrm{mg} \mathrm{kg}^{-1}\right.$ dry weight $)$ & 64268.16 & 17126.12 & 104604.55 & 57019.33 & 66127.47 & 9433.65 \\
\hline \multicolumn{7}{|l|}{ Sediments } \\
\hline LPAH (mg kg ${ }^{-1}$ dry weight) & 0.84 & 0.22 & 1.01 & 0.30 & 1.82 & 1.94 \\
\hline HPAH (mg kg ${ }^{-1}$ dry weight) & 0.66 & 0.40 & 0.64 & 0.25 & 0.61 & 0.60 \\
\hline TPAH (mg kg ${ }^{-1}$ dry weight) & 1.51 & 0.50 & 1.65 & 0.54 & 2.43 & 1.99 \\
\hline
\end{tabular}

LPAH low-molecular-weight PAH, HPAH high-molecular-weight PAH, TPAH total PAH 
found for dissolved and particulate metal mean concentrations, being higher concentrations in Tinto and Odiel sampling sites, except for $\mathrm{Pb}$ with similar values between Tinto and Canal del Padre Santo and lower than those founded in Odiel point.

Otherwise, high percentages of particulate metal were obtained for $\mathrm{Pb}(13.9-85.1 \%)$ with a seasonal variation, increasing in spring samples. $\mathrm{Cu}$, with percentages ranging from 32.7 to $88.2 \%$, did not show clear variability with surveys. Zn particulate fraction increased in spring samples and sometimes constituted $54-66 \%$ of the total metal in water. Cd appeared mainly in dissolved fraction, although particulate fraction increased 43.7-73.6\% during the last sampling. As in water was found principally as dissolved metal (82.6-99.5\%) in all sampling, being more available as this fraction. So, metals arranged by higher percentages of dissolved (related with more availability) were as follows: $\mathrm{As}>\mathrm{Cd}>\mathrm{Zn}>\mathrm{Pb}$ $>\mathrm{Cu}$ with following average percentages, 91.5, 67.3, $61.1,40.7$ and $40.1 \%$, respectively.

In order to assess the potential hazardous impacts, the heavy metal levels in water were also compared with background and natural guidelines (Förstner and Wittmann 1983; Azcue 1993), quality guidelines for protection of aquatic life proposed by several organizations guidelines (USEPA 2002) and imperative values of regional government (BOJA 1997). Metal concentrations studied were considerably higher than background values and nature concentrations in water. However, concentration values of $\mathrm{As}, \mathrm{Cd}$ and $\mathrm{Pb}$ were lower than those proposed by EPA criteria of maximum concentration (CMC) and continuous concentration (CCC), both established to prevent from acute and chronic toxicity to aquatic organisms, respectively. Levels of dissolved $\mathrm{Cu}$ were higher than CCC and $\mathrm{CMC}$ guides (five times). Imperative values of regional government proposed for $\mathrm{Cu}, \mathrm{Cd}$ and $\mathrm{Zn}$ were exceeded in all sites for the majority of the samples, principally in Tinto and Odiel sites.

\section{Metal concentration in sediment}

The metal concentrations (average values) for each sampling site and date found in sediment of Ría de Huelva are shown in Table 1. Metal contents were ranging over following intervals: $\mathrm{Zn}$, 602.94-1736.9 $\mathrm{mgkg}^{-1}$; Cd, 1.5-33.2 $\mathrm{mgkg}^{-1}$; $\mathrm{Pb}$,
136.8-1166.7 $\mathrm{mgkg}^{-1}$; Cu, 1115.7-3333.6 $\mathrm{mgkg}^{-1}$; As, $85.1-615.4 \mathrm{mgkg}^{-1}$. The high values for all metals were obtained for sampling of 2005, especially for $\mathrm{Cd}$ and $\mathrm{Pb}$ during autumn, coinciding with a period of low rainfalls. Metal from higher to lower mean content in the estuary was: $\mathrm{Cu}>\mathrm{Zn}>\mathrm{Pb}>\mathrm{As}>\mathrm{Cd}$.

The total metal concentrations in sediments were evaluated as the phase's sum of the speciation scheme.

Data on distribution of metals in fractions of BCR procedure can be consulted in Vicente Martorell et al. (2009). The distribution in fractions of studied metals remained homogeneous, and significant differences were not found between sampling for any metal. $\mathrm{Zn}$ and $\mathrm{Cd}$ appeared mainly bound to weak acid and carbonates being more available. In the case of $\mathrm{Cu}$, it appeared mainly associated with oxidizable fraction, although reducible and exchangeable fractions were important too. $\mathrm{Pb}$ was associated with reducible, oxidizable and residual fractions, and fraction of this metal bound to weak acid was not observed. As was the least available metal studied, appearing is mainly associated with residual fraction $(70 \%)$ which represents metals largely embedded in the crystal lattice of the sediment fraction and should not be available for remobilization except under extreme conditions. Results did not show significant variations between sampling sites, except for $\mathrm{Cu}$ that had higher reducible fraction in Padre Santo Canal than in Odiel River and Tinto River.

Based on the study of distribution of metals in sediments of Huelva estuary, they can be arranged from more available to less available as follows: $\mathrm{Cd}>\mathrm{Zn}>\mathrm{Cu}>\mathrm{Pb}>$ As.

Concentrations of heavy metals in sediments were compared with Canadian sediment quality guidelines (2001) (ISQG, interim marine sediment quality guidelines and PEL, probable effects levels) and NOAA guidelines for the protection of aquatic life (ERL, level of effects range low and ERM, level of effects range medium) (Irwin et al. 1997; Long et al. 1995; MacDonald et al. 2000). All metals studies showed higher concentrations than quality criteria, outstanding $\mathrm{Cu}$ with very high values. $\mathrm{Pb}$ which some lower values than ERM guideline on 2004 autumn was an exception; in addition, Cd exceeded ERL and ISQG criteria for all samples and PEL criterion during autumn 2005. The increase in heavy metals in autumn 2005 could be due to a long period of low rainfalls. 

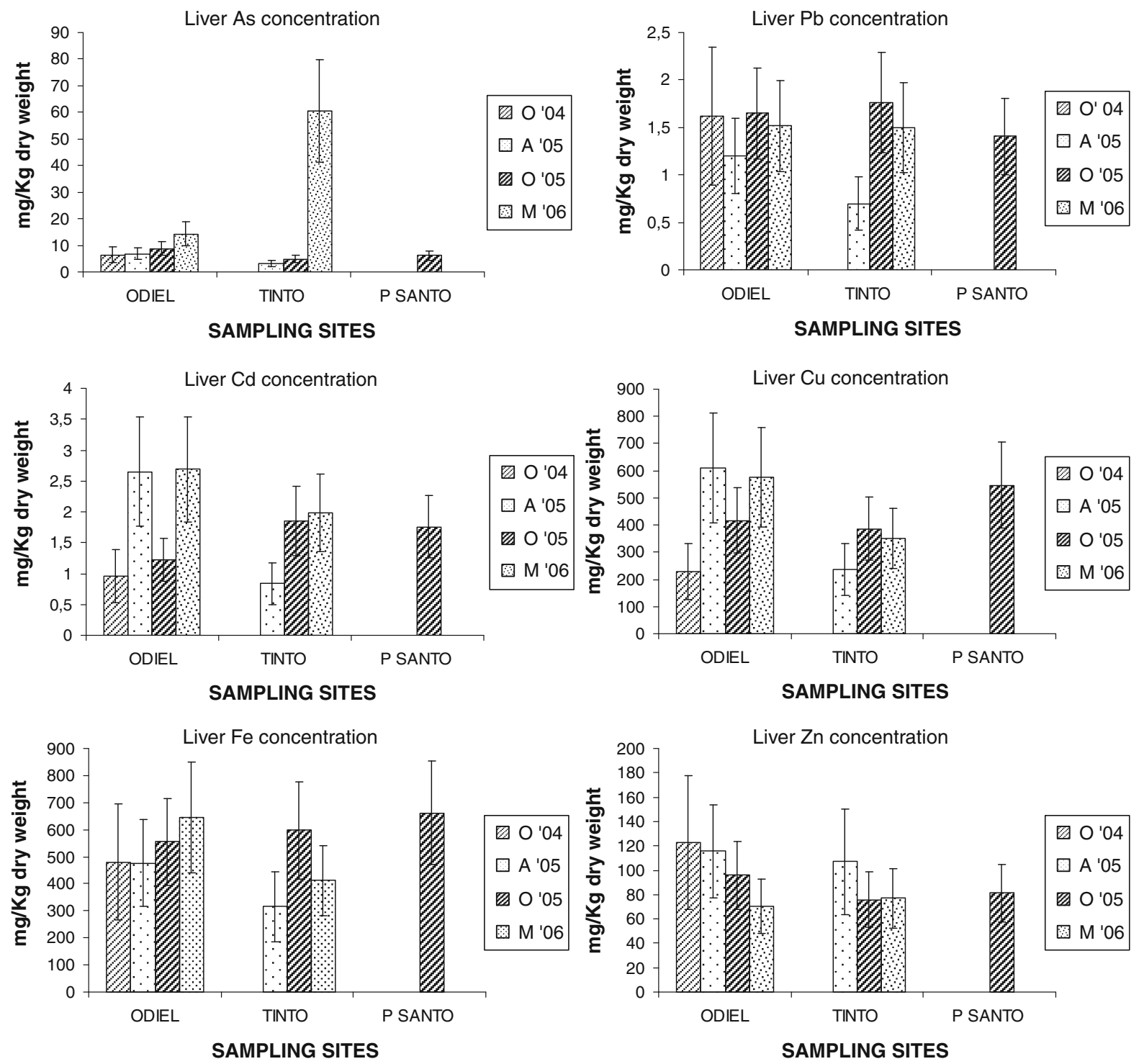

Fig. 2 Average concentrations of the heavy metals $\mathrm{As}, \mathrm{Pb}, \mathrm{Cu}, \mathrm{Zn}, \mathrm{Fe}$ and $\mathrm{Cd}(\mathrm{mg} / \mathrm{kg}$ d.w.) in the liver of $S$. senegalensis collected in 2004, 2005 and 2006 years with corresponding ES bars ( $O$ October, $A$ April, $M$ may)

Metal concentration in liver and gills of S. senegalensis

Average metal concentrations in liver and gills of S. senegalensis are shown in Figs. 2 and 3. The higher mean contents of $\mathrm{Zn}, \mathrm{Cd}, \mathrm{Cu}$ and As were found in liver and of $\mathrm{Pb}$ in gill. Comparing mean concentration in tissues, gill showed the following accumulation ranking: $\mathrm{Zn}>\mathrm{As}>\mathrm{Cu}>\mathrm{Pb}>\mathrm{Cd}$ while liver had the following one: $\mathrm{Cu}>\mathrm{Zn}>\mathrm{As}>\mathrm{Cd}>\mathrm{Pb}$.

Generally, the levels of metal in liver samples were higher than FAO/WHO limits values, but these ones are usually referred to muscle and fish pool not being comparables.

PAHs concentrations in sediments

PAHs concentrations founded in sediments of the studied areas are presented in Table 1 (average values obtained at each sampling point for the four sampling campaigns, October 2004 to May 2006). The higher concentration of PAHs with less than 3 aromatic rings (LPAHs) was observed in the sediment of Padre Santo Canal (Table 1); this is the sampling site more polluted by PAHs of the 

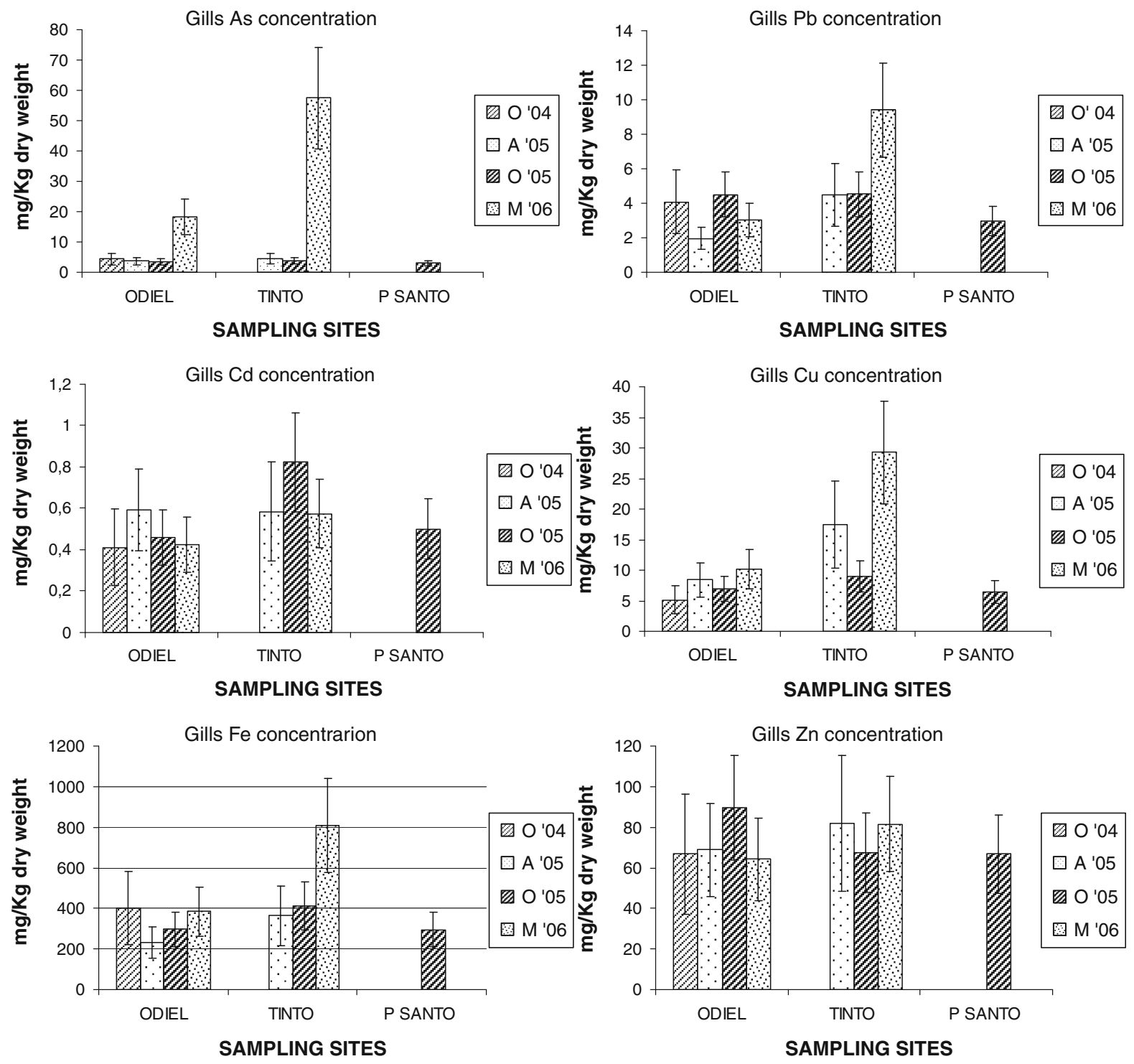

Fig. 3 Average concentrations of the heavy metals $\mathrm{As}, \mathrm{Pb}, \mathrm{Cu}, \mathrm{Zn}, \mathrm{Fe}$ and $\mathrm{Cd}$ (mg/kg d.w.) in the gills of $\mathrm{S}$. senegalensis collected in 2004, 2005 and 2006 years with corresponding ES bars ( $O$ october, $A$ april, $M$ may)

Huelva estuary. Roy et al. (2003) observed higher PAHs of low molecular weight in coal oil point (COP) sediments than high molecular PAHs. This is consistent with previous studies showing that natural petroleum seeps lend to have higher concentrations of lower molecular weight aromatic hydrocarbons (Spies et al. 1980). To establish the contamination grade for PAHs in the different sampling sites, the level of PAHs observed was compared with the Holand Environmental Quality Criteria to Marine Sediments (Kamer 1994).
This criterion is established in basis to the summatory of 10 PAHs (naphthalene, phenanthrene, anthracene, fluoranthene, chrysene, benzo(a)anthracene, benzo(k)fluoranthene, benzo(b)-fluoranthene, benzo(g)perylene and indene). The summatory of those PAHs in Odiel River was $0.68,0.82 \mathrm{mg} / \mathrm{kg}$ in the Tinto River and $1.81 \mathrm{mg} / \mathrm{kg}$ dry weight in Padre Santo Canal. Conform to this criteria, Odiel and Tinto River was classified as no or few contaminated sites and Padre Santo Canal is classified as moderately 
contaminated site, where a high concentration of LPAHs was observed in the sediment.

PAHs metabolites in liver and gills of

S. senegalensis

PAHs concentrations observed in hepatic tissue and gills were very low, zero or undetectable in most samples (data unpublished); for this reason only have been conducted correlations between PAHs metabolites in liver and gills and histopathological alterations.

PAHs metabolites in gills and hepatic tissue of fish from different sampling sites are showed in Figs. 4 and 5. Pyrene metabolite-types showed the higher concentrations in gills and liver tissues, followed by napahthalene, benzo(a)pyrene and phenanthrene metabolite-types.

\section{Histopathological alterations}

Seven major types of histopathological lesions were observed in gills of S. senegalensis: Aneurysms, hypertrophy of the lamellar epithelia, hyperplasia of the lamellar epithelia, hypertrophy of cartilage, lamellar fusion, desquamation of the lamellar epithelia and epithelial lifting (Fig. 6). Gills from S. senegalensis showed a high prevalence of hyperplasia and desquamation of the lamellar epithelia (Table 2). The higher lesion grade was observed in aneurysm, hyperplasia and lifting of the lamellar epithelia (Table 2).

Six major types of histopathological lesions were observed in liver: Esteatosis, vacuolization, necrosis, blood stagnation, leucocitary infiltration and hepatic parenchyma disorganization (Fig. 7). The alterations with higher prevalence (Table 2) observed in liver were necrosis and hepatic parenchyma disorganization. The higher lesion grade was observed in vacuolization, blood stagnation and hepatic parenchyma disorganization in liver (Table 2).

Significant differences was observed in the lesion grade of gills, and hepatic alterations between seasons (fish captured in autumn presented, in general, alterations with higher lesion grade respect to fish captured in spring season) (chi-square Test, $p<0.05$, $v=0.661$ ) and significant differences between sampling sites were also observed, showing Odiel river, the alterations with a higher lesion grade (chi-square Test, $p<0.05, v=0.574)$.
No significant differences were observed in the alterations prevalence between sampling sites, but significant differences were observed between seasons for pathologies such us aneurysms and desquamation of the epithelia in gills and disorganization of parenchyma in liver being the prevalence higher in autumn season.

Relationship between alterations prevalence and heavy metal concentrations

Significant correlations were established between heavy metals concentrations in alterations in S. senegalensis. Positive correlations were established between heavy metal concentrations in sediments and alterations in gills: aneurysms with arsenic and zinc; hypertrophy of the lamellar epithelium with lead and iron; hyperplasia of the lamellar epithelia with arsenic, lead, cadmium, copper and iron; and hypertrophy of cartilage with iron concentration. A positive correlation was also observed between iron concentration in sediment and blood stagnation in liver (Table 3).

Positive correlations were also established between heavy metal concentrations in water and gill alterations such as lamellar fusion (zinc), desquamation of the lamellar epithelia (copper) and lifting of the lamellar epithelia (lead and copper). Hepatic necrosis was correlated with arsenic, cadmium, copper and zinc concentrations in water (Table 3).

No positive correlations were observed between heavy metals concentrations in tissues and alterations.

Relationship between alterations prevalence and PAH concentrations

Only one positive correlation was established, specifically between necrosis hepatic and benzo(a)anthracene concentration in sediments ( $p=0.022, r=0.704)$. No positive correlations were observed between PAHs metabolites in gills and liver and histopathological alterations.

\section{IPAT index}

IPAT index showed in general a low impact of pollutants on fish health; only the first samplings in October 2004 showed a moderate impact on health fish (Table 4). The impact of pollutants was decreasing with the time. No significant differences $(p \leq 0.05)$ 
Benzo(a)Pyrene-type Metabolites

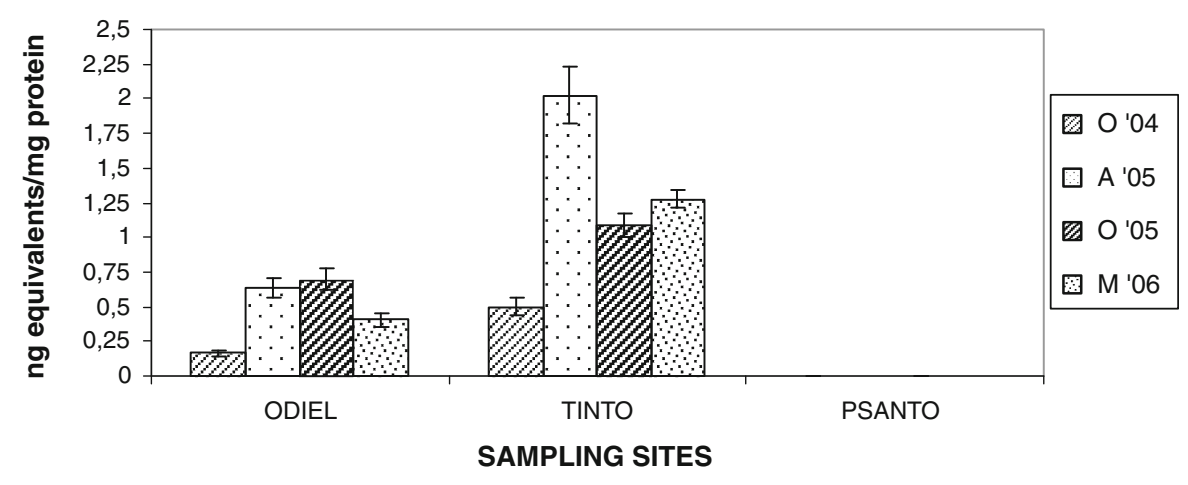

Naphthalene type Metabolites

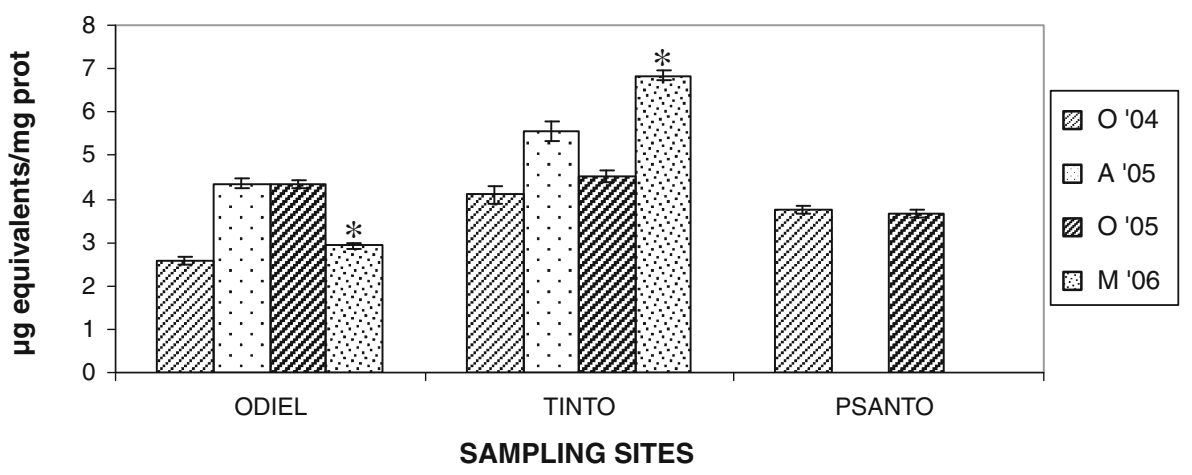

Pyrene-type Metabolites
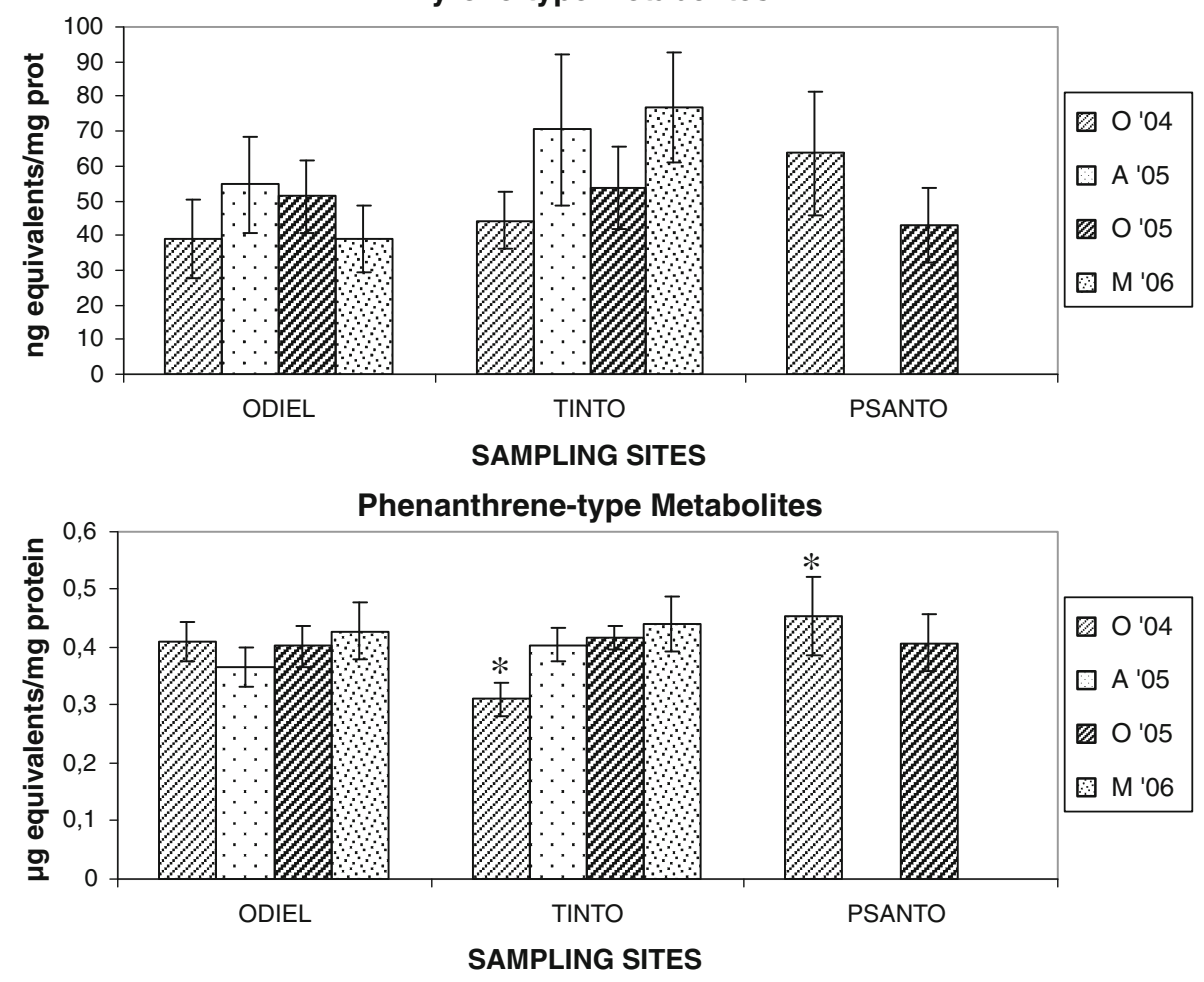
4 Fig. 4 PAHs metabolites (average and standard error) in liver of $S$. senegalensis captured from the different sampling sites in 2004, 2005 and 2006 year. ( $O$ october, $A$ april, $M$ may). Asterisks denote means are significantly different in the same season $(p<0.05)$

were observed between sampling sites, but significant differences were observed between seasons being autumn the season with higher IPAT index (Fig. 8).

\section{Discussion}

As part of a comprehensive programme, this study emphasizes the use of histopathological investigations for assessing the effects of contaminants on the health of $S$. senegalensis from Huelva estuary.

Histopathological alterations in fish may decrease individual fitness through disturbing the homoeostasis and proper functioning of vital biological processes (e.g. detoxification, endocrine functioning, respiration, osmoregulation and nutrient absorption) and leading to deleterious population effects.

IPAT index demonstrated a recuperation of estuary system with the time. The methods for evaluating histopathological lesions are rather divergent (Adams et al. 1993; Bernet et al. 1999; Fernandes et al. 2007, 2008; Delatim Simonato et al. 2008; Costa et al. 2009). The use of different methods and assessment scales as well as the inclusion of different histological changes has always made it difficult to compare different studies. Therefore, a standardized assessment method is needed. With the quantification of the lesions, statistical evaluation becomes practicable. The corresponding indices can be compared more easily than morphological descriptions of pathological changes. Although histopathology is a descriptive science, the assessment of the lesions allows a more reliable comparison of different studies.

Significant differences were observed in lesion grade, lesion prevalence and IPAT index between seasons observing in autumn the highest impact of pollutants.

Stentiford et al. (2003) also observed an increase in hepatic alterations in autumn respect to spring season, but it cannot be excluded that these differences were associated with seasonal spawning and feeding migrations of the sole.

Different correlations were established between heavy metals and histopathological alterations of the different tissues of $S$. senegalensis.
Arsenic has been correlated with aneurysms and hyperplasia in gills and hepatic necrosis. Arsenic is a metalloid that is prevalent in the environment, occurring both naturally and as a consequence of pollution. In aquatic environments, exposure to arsenic has been shown to interfere with chloride ion homoeostasis in fish, presumably by activating the ubiquitin-lysosomal degradation of cystic fibrosis transmembrane conductance regulator chloride channels (Shaw et al. 2007).

Alterations similar to the described in this work have been observed in fish exposed to As in both laboratory and field (Gilderhus 1966; Sorenson 1980, 1991; Chang et al. 1998; Kotsanis and IliopoulouGeorgudaki 1999; Pedlar 2000).

Roy et al. (2003) observed in liver of Channa punctatus exposed to $7.6 \mathrm{mg} / \mathrm{L}$ arsenic to lose the regular shape of hepatic cells, necrosis, disintegration of sinusoids, blood congestion and parenchyma disintegration. Pedlar et al. (2002) observed in Coregonus clupeaformis exposed to $0.1 \mathrm{mg} / \mathrm{g}$ food of arsenic disruption of the hepatocytes cord structure, indistinguishable cell outlines, areas of hepatocytes with eosinophilic cytoplasm and aggregations of lymphocytes. Livers of green sunfish (L.cyanellus) collected from Finfeather Lake, which had a mean sediment As concentration of $4,700 \mu \mathrm{g} / \mathrm{g}$ dry weight, contained abnormally shaped parenchymal hepatocytes arranged in a disorganized fashion, such that the two-cell thick cord structure was disrupted, as well as exhibiting pronounces focal necrosis (Sorenson et al. 1980).

In liver, arsenate is reduced to arsenite (Yamauchi and Fowler 1994; Shiomi et al. 1996; Styblo et al. 1999; McGeachy and Dixon 1990; Rankin and Dixon 1994), so that toxic effects may be caused by both compounds. The mechanisms through which As results in hepatic alterations remain to be elucidated; however, they may involve uncoupling of oxidative phosphorylation due to arsenate substitution for phosphate, enzyme inhibition as a result of arsenite interaction with thiolcontaining proteins, and/or elevated lipid peroxidation (Hindmarsh and McCurdly 1986; Fowle et al. 1992; Okada and Yamanaka 1994).

According with correlations between arsenic and histopathological alterations in S. senegalensis observed in this work, alterations such as aneurysms, hyperplasia of the epithelia and lamellar fusion were observed in gills of $S$. senegalensis exposed to $75 \mathrm{mg} / \mathrm{L}$ of arsenic (Data unpublished). 
Fig. 5 PAHs metabolites (average and standard error) in gills of $S$. senegalensis captured from the different sampling sites in 2004, 2005 and 2006 year ( $O$ october, $A$ april, $M$ may). Asterisks denote means are significantly different in the same season $(p<0.05)$
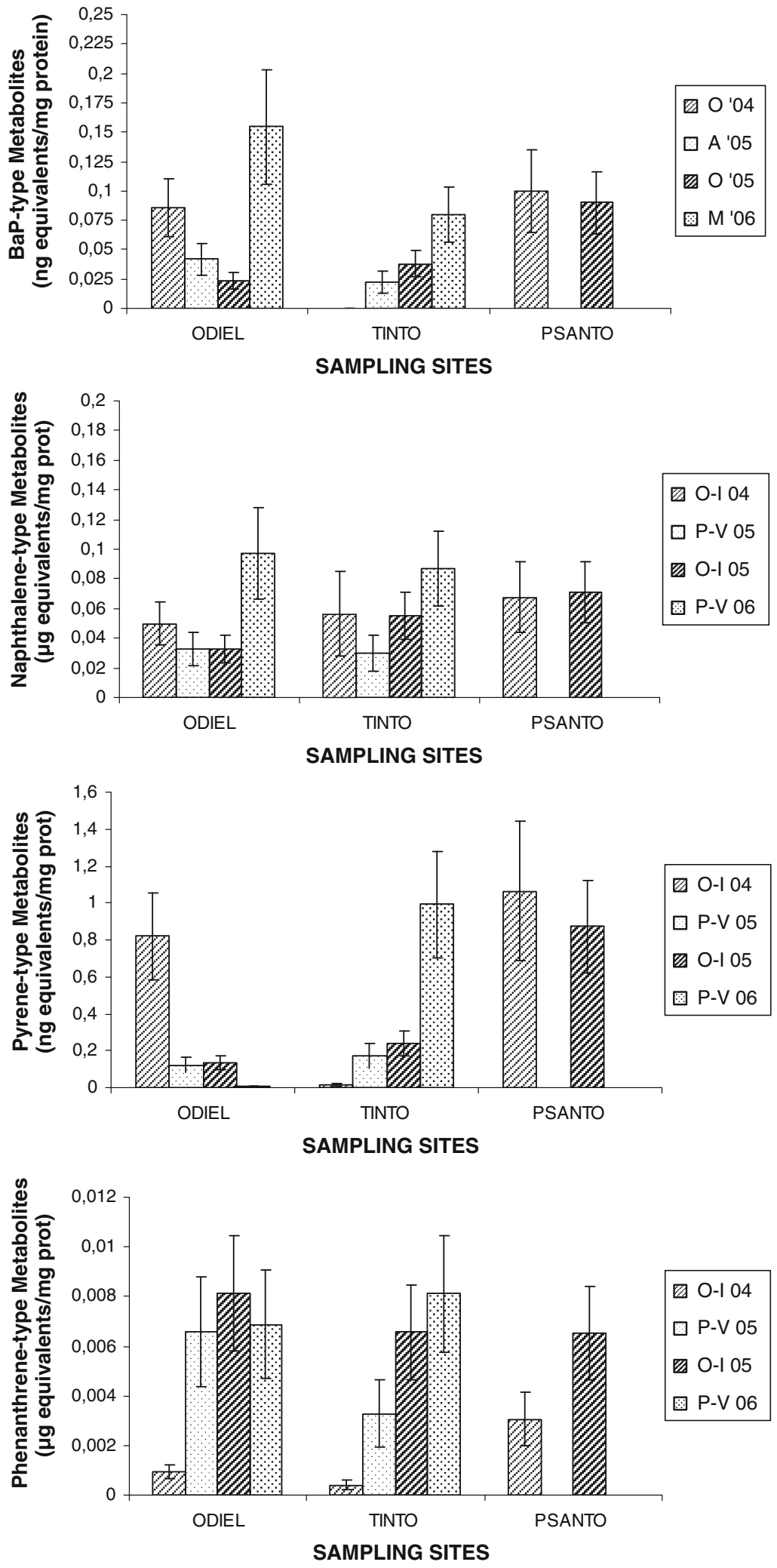


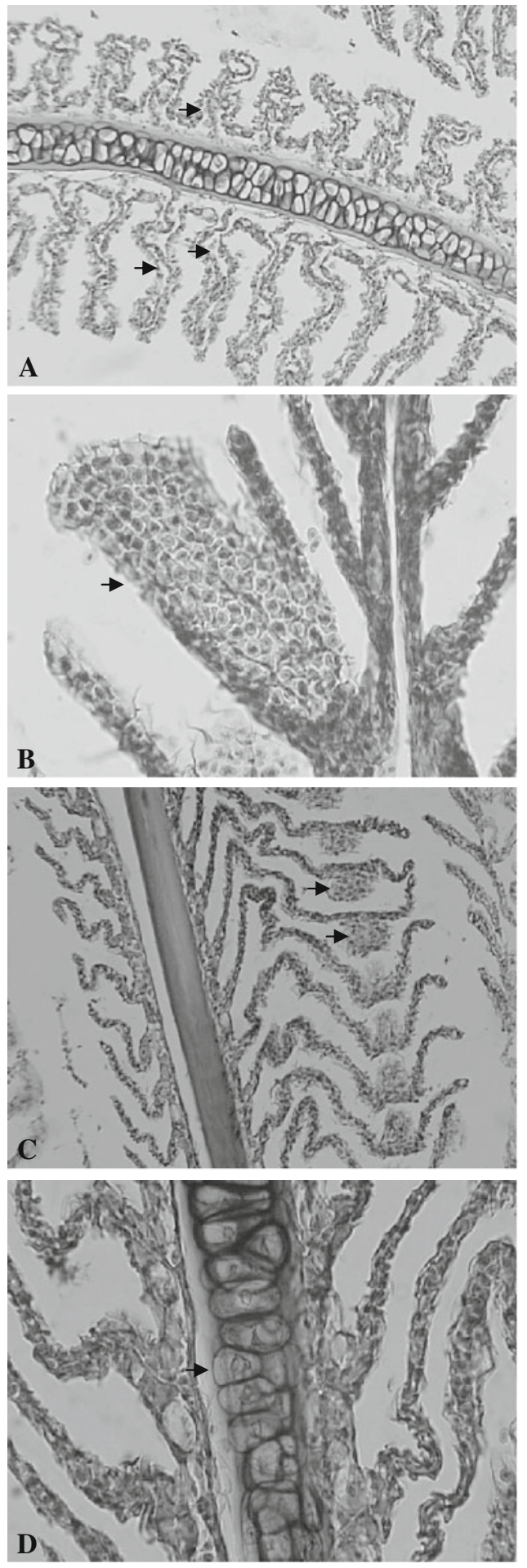

Fig. 6 Gill alterations in $S$. senegalensis from Huelva estuary. a Epithelial lifting $(\mathrm{H} / \mathrm{E} \times 10)$. b Hyperplasia of epithelia in secondary lamellae $(\mathrm{H} / \mathrm{E} \times 25)$. c Aneurysms in secondary lamellae $(\mathrm{H} / \mathrm{E} \times 10)$. d Hypertrophy of cartilage $(\mathrm{H} / \mathrm{E} \times 25)$
Lead has been also correlated with alterations such as hypertrophy, hyperplasia and lifting of lamellar epithelia of $S$. senegalensis. The presence of $\mathrm{Pb}$ in marine water is due to a variety of anthropogenic activities related to the increasing mining operations and industrial use. In aquatic biota, $\mathrm{Pb}$ concentrations are usually highest in benthic organisms and lowest in upper trophic level predators.

Several authors have observed similar effects of lead on fish gills. Roncero et al. (1990) observed in Tinca tinca exposed to $75 \mathrm{mg} / \mathrm{L} \mathrm{Pb}$ a decrease in the surface area of the secondary lamella due to cellular hyperplasia, necrosis and oedema of the respiratory epithelium was observed in the medio-distal region of the lamellae. Martínez et al. (2004) observed in gills of Prochilodus lineatus exposed to $71 \mathrm{mg} / \mathrm{L} \mathrm{Pb}$ epithelial lifting, hyperplasia with occasionally fusion of adjacent lamellae and erythrocyte congestion (aneurysm) throughout the entire lamella. Lifting of epithelium or hyperplasia of epithelium results in an increase in the diffusion distance (distance separating blood lacuna in the lamellae from the external medium), thus affecting exchange of gases.

Cadmium has been correlated with alterations such as hypertrophy of lamellar epithelia and hepatic necrosis in S. senegalensis. Cadmium is a ubiquitous, essential heavy metal widely used in several industries and well known as a highly toxic pollutant. Histological studies and the toxicity of cadmium to fish have been investigated by many scientists. Generally, the external effects of cadmium poisoning illustrated by abnormal swimming behaviour observed in different fish species occur after significant damage to the internal organs. Examination of fish tissue prior to external manifestation of poisoning has served to establish the extent of damage done by cadmium and perhaps the mode of action of the metal.

Oronsaye (1989) observed in Gasterosteus aculeatus exposed to dissolved cadmium in hard water effects dependent on the lengths of exposure and the cadmium concentrations. The sequence of changes followed and essentially definite pattern in all concentrations tested. There was the swelling and lifting up of epithelial layers of the secondary lamellae, and vacuolization of the gill filament. The spaces created in the secondary lamellae were occupied by the chloride cells. The secondary lamellae of the basal areas of the gill filaments were seen to be fused with 


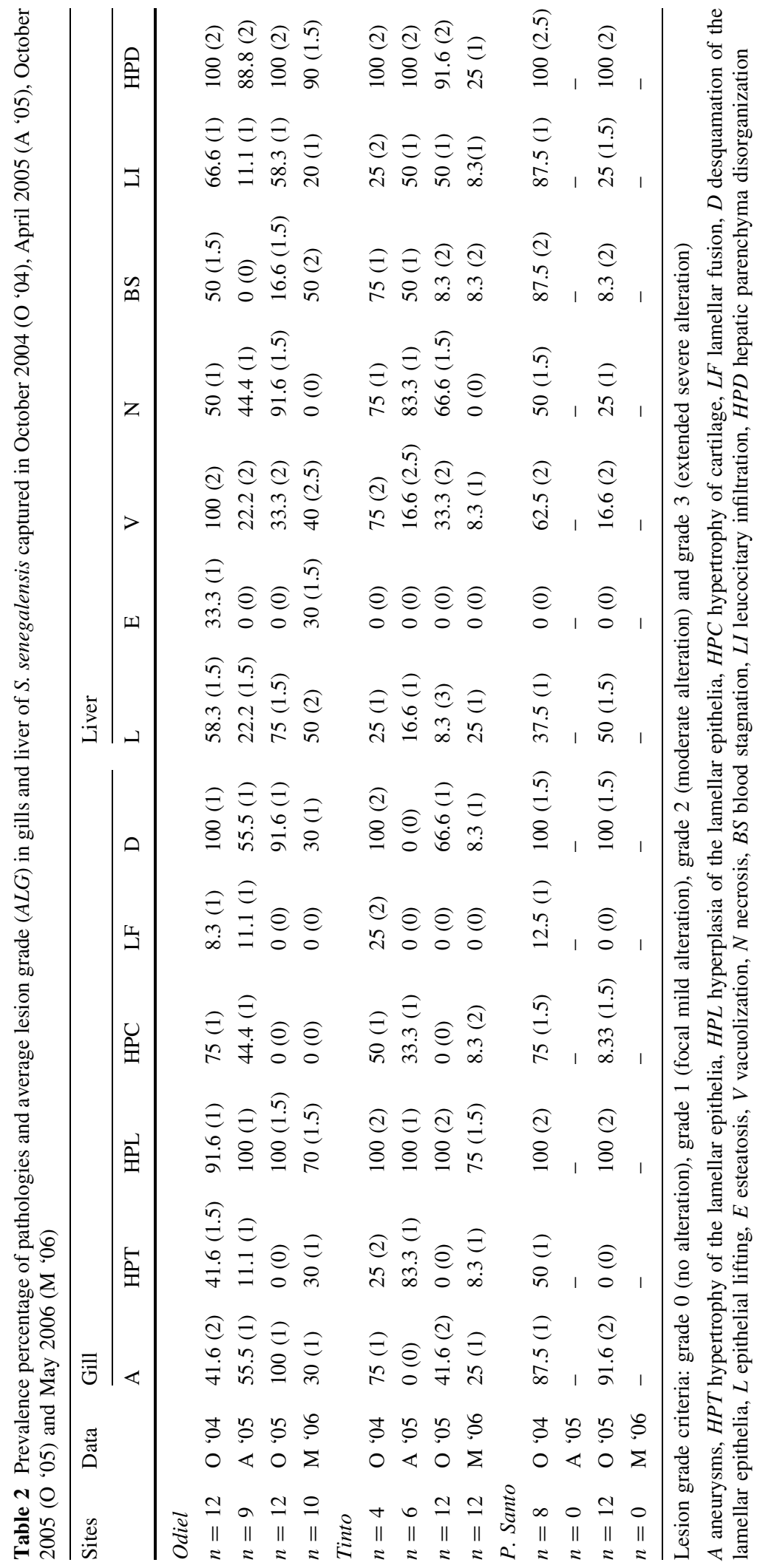



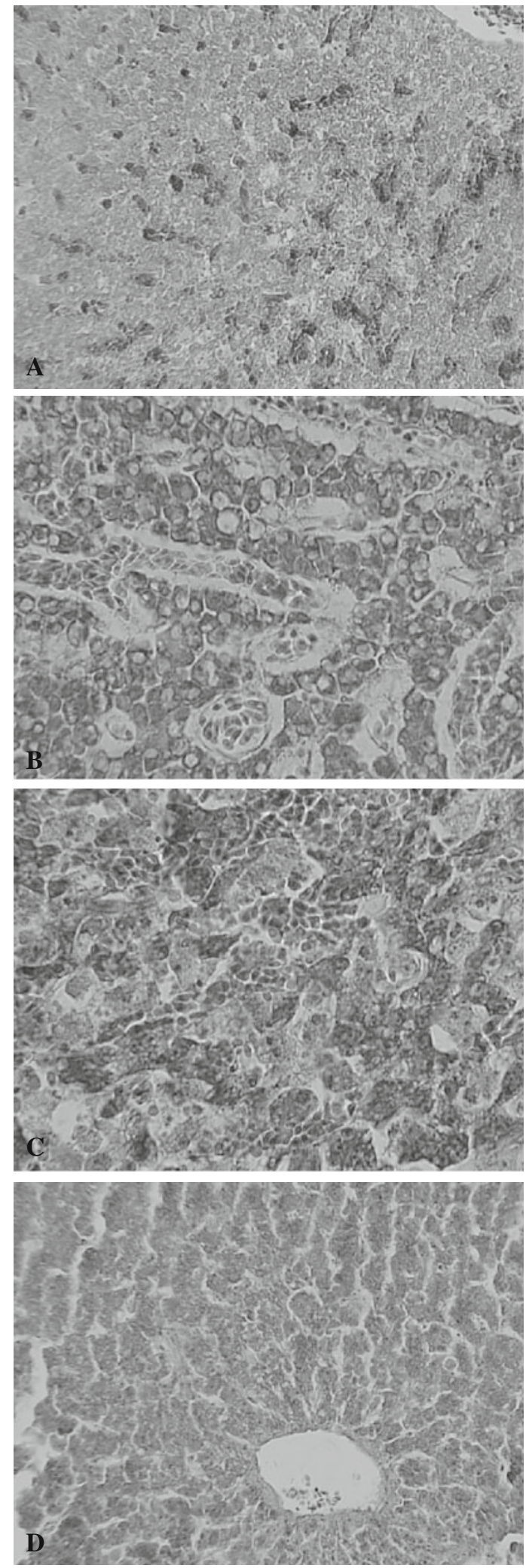

4 Fig. 7 Hepatic alterations in $S$. senegalensis from Huelva estuary. a Blood stagnation $(\mathrm{H} / \mathrm{V} \times 10)$. b Hydropic vacuolation $(\mathrm{H} / \mathrm{E} \times 25)$. c Necrosis $(\mathrm{H} / \mathrm{E} \times 25)$. d Disorganization of hepatic parenchyma. Hepatocytes in clusters $(\mathrm{H} / \mathrm{E} \times 10)$

the gill arch and those of adjacent fill filaments. The distal portions were similarly affected. The entire gill filament and the interlamellar spaces were now seen as solid masses of cells.

Usha Rani and Ramamurthi (1989) also observed in Tilapia mossambica exposed to sublethal concentrations of cadmium vacuolar degeneration of the hepatocytes surrounding pancreatic cells of liver and congestion of the blood vessels. Corresponding with the cellular damage, a significant loss of liver protein, with an increase in ammonia and urea levels, and impaired hepatic oxidative metabolism were observed in the cadmium exposed fish (Usha Rani 1986).

Thophon et al. (2003) observed in gills of Later calcarifer exposed to suchronic concentrations of cadmium an extensive oedema of the epithelial cells, and blood congestion (aneurysm) in many areas of secondary lamellae with the breakdown of the pillar cell system. An extensive hypertrophy and hyperplasia of chloride cells and mucus cells at the base of the gill filaments and secondary lamellae were also observed. The liver of L. calcarifer showed blood congestion in sinusoids and hydropic vacuolization of hepatocytes, and Wangsongsak et al. (2007) observed in gills of Puntios gonionotus exposed to subchronic cadmium exposure hyperplasia of pillar and epithelial cells, hypertrophy and a thickening of primary lamellar epithelium.

The pathological changes, like vacuolar degeneration of hepatocytes and necrosis, can be attributed to the physiological alterations observed in the liver tissue leading to the accumulation of lactate under low-oxygen tension produced by the effect of cadmium on gills.

Previous studies found that cadmium was taken up across the epithelial layer of fish gills (Verbost et al. 1987, 1989) via calcium channels (Farag et al. 1994; Wicklund-Glynn et al. 1994). Calcium is known to exert considerable control over the permeability of the gills, and displacement of calcium could stimulate ion loss and water uptake (Reid and McDonald 1991). Cadmium affects calcium balance in rainbow trout (Verbost et al. 1987) and induces damage in gill structure of zebra fish, rainbow trout and tilapia (Karlsson-Norrgren et al. 1985; Part et al. 1985; Pratap 
Table 3 Correlation coefficients $(r)$ of the significant correlations $(p \leq 0.05)$ between alterations prevalence and metal concentrations in sediments and water samples

\begin{tabular}{|c|c|c|c|c|c|c|c|c|c|c|c|}
\hline \multirow[t]{2}{*}{ Fraction } & \multicolumn{11}{|c|}{ Alterations } \\
\hline & A & HPT & HPL & $\mathrm{HPC}$ & LF & $\mathrm{D}$ & $\mathrm{L}$ & $\mathrm{N}$ & BS & LI & HPD \\
\hline \multicolumn{12}{|l|}{ Sediments } \\
\hline As I & & & 0.679 & & & & & & & & \\
\hline As II & & & 0.649 & & & & & & & & \\
\hline As III & 0.760 & & & & & & & & & & \\
\hline $\mathrm{Pb}$ II & & & 0.753 & & & & & & & & \\
\hline $\mathrm{Pb}$ III & & & 0.798 & & & & & & & & \\
\hline $\mathrm{Pb} \mathrm{R}$ & & 0.730 & & & & & & & & & \\
\hline Cd I & & & 0.679 & & & & & & & & \\
\hline $\mathrm{Cu} \mathrm{R}$ & & & 0.679 & & & & & & & & \\
\hline $\mathrm{Fe} I$ & & 0.742 & & 0.652 & & & & & 0.838 & & \\
\hline Zn I & 0.766 & & & & & & & & & & \\
\hline Zn II & 0.839 & & 0.723 & & & & & & & & \\
\hline $\mathrm{Zn} \mathrm{T}$ & 0.687 & & & & & & & & & & \\
\hline \multicolumn{12}{|l|}{ Water } \\
\hline As particulate & & & & & & & & 0.695 & & & \\
\hline $\mathrm{Pb}$ no labile & & & & & & & 0.634 & & & & \\
\hline $\mathrm{Pb}$ dissolved & & & & & & & 0.737 & & & & \\
\hline Cd no labile & & & & & & & & 0.704 & & 0.726 & \\
\hline $\mathrm{Cu}$ labile organic & & & & & & 0.658 & & & & & \\
\hline Cu Mod Lab In & & & & & & & 0.733 & & & & \\
\hline $\mathrm{Cu}$ no labile & & & & & & & & 0.667 & & & \\
\hline Zn Mod Lab Or & & & & & 0.760 & & & & & & \\
\hline Zn no labile & & & & & & & & 0.654 & & 0.972 & 0.719 \\
\hline
\end{tabular}

$I$ exchangeable, $I I$ reducible, $I I I$ oxidizable, $R$ residue, $T$ total, In inorganic, $O r$ organic, Lab labile, Mod moderately, $A$ aneurysms, $H P T$ hypertrophy of the lamellar epithelia, $H P L$ hyperplasia of the lamellar epithelia, $H P C$ hypertrophy of cartilage, $L F$ lamellar fusion, $D$ desquamation of the lamellar epithelia, $L$ epithelial lifting, $N$ necrosis, $B S$ blood stagnation, $L I$ leucocitary infiltration, $H P D$ hepatic parenchyma disorganization

and Wendelaar Bonga 1993). Lamellar aneurysm is produced by the collapse of the pillar cell system and the breakdown of vascular integrity with a release of large quantities of blood that push the lamellar epithelium outward (Alazemi et al. 1996). Several studies pointed out that the chloride cell hyperplasia occurred in response to the need to eject the cadmium absorbed by the gills (Fu et al. 1990).

Giari et al. (2007) observed in gills of Dicentrarchus labrax exposed to $8.91 \mathrm{mg} / \mathrm{L}$ cadmium alterations such as telangectasia, diffuse oedema and detachment of the lamellar epithelium (=epithelial lifting) with the formation of large subepithelial spaces within the secondary lamellae; partial or complete secondary lamellar fusion and thickening of primary lamellae with chloride cells hyperplasia, necrosis and leucocyte infiltration (granulocytes and macrophages) in secondary lamellae were also observed. In liver, large lipid droplets were accumulated in many hepatocytes (steatosis); diffuse degenerative vacuolization (cellular oedema or acute cell swelling) and cytoplasm rarefaction were observed. A statistical analysis of common gill histopathology indicates that structural damages such as hyperplasia with lamellar fusion, telangectasia, oedema, epithelial lifting and necrosis represent stereotyped physiological reactions of gill to stress and many of them have a defence function (Mallat 1985). These responses, whether adaptive or pathological, invariable determine the extent of homoeostatic regulation of the 
Table 4 IPAT index of the different sites in October 2004 (O ‘04), April 2005 (A ‘05), October 2005 (O ‘05) and May 2006 (M ‘06)

\begin{tabular}{|c|c|c|c|c|c|c|c|c|c|c|c|c|c|c|c|}
\hline \multirow[t]{2}{*}{ Sites } & \multirow[t]{2}{*}{ Data } & \multicolumn{6}{|l|}{ Gill } & \multicolumn{8}{|l|}{ Liver } \\
\hline & & $\mathrm{A}(1)$ & HPT(1) & HPL(2) & HPC (1) & $\mathrm{LF}(1)$ & $\mathrm{D}(1)$ & $\mathrm{L}(1)$ & $\mathrm{E}(1)$ & $\mathrm{V}(3)$ & $\mathrm{N}(3)$ & $\mathrm{BS}(1)$ & $\mathrm{LI}(2)$ & $\operatorname{HPD}(1)$ & IPAT \\
\hline \multicolumn{16}{|l|}{ Odiel } \\
\hline$n=12$ & O ‘04 & 83.2 & 62.4 & 183.2 & 75 & 8.3 & 100 & 87.45 & 33.3 & 600 & 150 & 75 & 133.2 & 200 & 17.9 \\
\hline$n=9$ & A ‘05 & 55.5 & 11.1 & 200 & 44.4 & 11.1 & 55.5 & 33.3 & 0 & 133.2 & 133.2 & 0 & 22.2 & 177.6 & 7.43 \\
\hline$n=12$ & $\mathrm{O} \cdot 05$ & 100 & 0 & 300 & 0 & 0 & 91.6 & 112.5 & 0 & 199.8 & 411.6 & 24.9 & 116.6 & 200 & 15.57 \\
\hline$n=10$ & M ‘06 & 30 & 30 & 210 & 0 & 0 & 30 & 100 & 45 & 300 & 0 & 100 & 40 & 135 & 10.2 \\
\hline \multicolumn{16}{|l|}{ Tinto } \\
\hline$n=4$ & O ‘04 & 75 & 50 & 400 & 50 & 50 & 200 & 25 & 0 & 450 & 225 & 75 & 100 & 200 & 19 \\
\hline$n=6$ & A ‘05 & 0 & 83.3 & 200 & 33.3 & 0 & 0 & 16.6 & 0 & 124.5 & 499.8 & 50 & 100 & 200 & 13.07 \\
\hline$n=12$ & $\mathrm{O} ` 05$ & 83.2 & 0 & 400 & 0 & 0 & 66.6 & 24.9 & 0 & 199.8 & 599.4 & 16.6 & 100 & 183.2 & 15.73 \\
\hline$n=12$ & M '06 & 25 & 8.3 & 125 & 16.6 & 0 & 8.3 & 25 & 0 & 49.8 & 0 & 16.6 & 16.6 & 25 & 3.16 \\
\hline \multicolumn{16}{|l|}{ P. Santo } \\
\hline$n=8$ & O ‘04 & 87.5 & 50 & 400 & 112.5 & 12.5 & 150 & 37.5 & 0 & 375 & 225 & 175 & 175 & 250 & 20.5 \\
\hline$n=0$ & A ‘05 & - & - & - & - & - & - & - & - & - & - & - & - & - & - \\
\hline$n=12$ & $\mathrm{O} \cdot 05$ & 183.2 & 0 & 400 & 12.49 & 0 & 150 & 75 & 0 & 96.6 & 75 & 16.6 & 75 & 200 & 12.83 \\
\hline$n=0$ & M '06 & - & - & - & - & - & - & - & - & - & - & - & - & - & - \\
\hline
\end{tabular}

Partial values are obtained as each average lesion grade multiplied by his prevalence and condition weight

A aneurisms, HPT hypertrophy of the lamellar epithelia, $H P L$ hyperplasia of the lamellar epithelia, $H P C$ hypertrophy of cartilage, $L F$ lamellar fusion, $D$ desquamation of the lamellar epithelia, $L$ epithelial lifting, $E$ esteatosis, $V$ vacuolization, $N$ necrosis, $B S$ blood stagnation, $L I$ leucocitary infiltration, $H P D$ hepatic parenchyma disorganization

internal environment (Laurent and Perry 1991), in particular decreasing the efficiency of gas exchange (Jagoe et al. 1996; Oliveira Ribeiro et al. 2002).

Copper has been correlated with hyperplasia, lifting and desquamation of lamellar epithelia and hepatic necrosis. Copper is an essential trace metal and is found in nuclear chromatin, mitochondrial cytochrome-c oxidase, tryptophan oxygenase, monamine oxidase, cytosolic superoxide dismutase, lysosomes and other subcellular fractions (Bunton and Frazier 1994). It is metabolized primarily by the liver and excreted into the bile and is transported in the blood bound to albumin and ceruloplasmin. When copper concentrations in the body increase, copper is stored in hepatic lysosomes bound to metallothionein, a lowmolecular-weight metal binding protein induced by rising levels of copper.

Hepatic necrosis was also observed by Roncero et al. (1992) in liver of Tinca tinca exposed 12 days to $75 \mathrm{mg} / \mathrm{L}$ copper. Copper ions inhibit the pyruvate dehydrogenase system from the outset, interrupting cell energy production (Bartik and Piskac 1981) and inhibiting sodium absorption. This modifies the permeability of the hepatocytes cell membrane (Robbins and Cotran 1984), giving rise to the functional inability of the hepatocytes to synthesize protein, represented in this case by ceruloplasmin, which forms the basis of poisoning process (Robbins and Cotran 1984). The progressive accumulation of copper in the liver parenchyma is a result of ceruloplasmin deficiency or its inability to conjugate copper accumulations in the liver. The progressive vacuolar degeneration is caused by the alteration of membrane structural lipids (Lanno et al. 1987), leading finally to necrosis and massive disintegration.

Arellano et al. (1999) observed lifting and peeling of the lamellar epithelium as common lesions in the Senegal sole gills after copper exposure. Lamellar fusion, hyperplasia, rupture of capillaries and, consequently, release of erythrocytes also occurred.

Oliva et al. (2009) observed in S. senegalensis exposed to copper hypertrophy and hyperplasia of secondary lamellar as well as hypertrophy of the cartilage. Lamellae tended to shrink and disappear in some cases. Additional observations included numerous aneurysms in gill filaments, lifting of gill epithelia.

Lauren and McDonald (1985) demonstrated that the acute exposure of rainbow trout to copper is correlated with a decline in blood $\mathrm{Na}^{+}$and $\mathrm{Cl}^{+}$ concentrations. Inflammatory responses and flaking of 


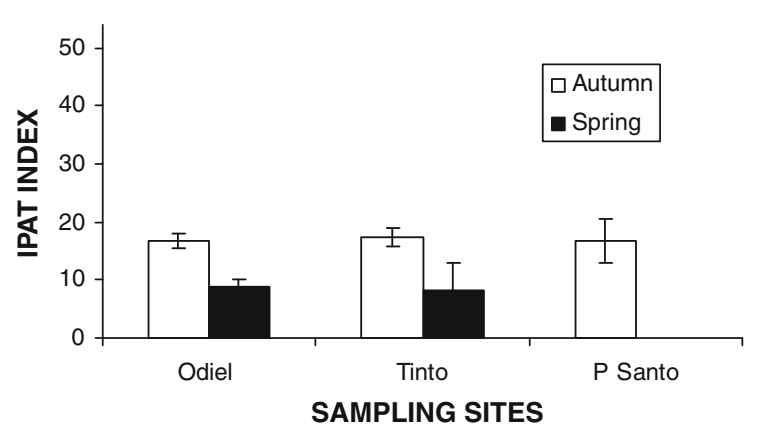

Fig. 8 IPAT index in different seasons and sampling sites

epithelial tissue could be related to a decrease in the gill $\mathrm{Na}^{+}, \mathrm{K}$-activated ATPase, and with a decline in blood $\mathrm{Na}^{+}$and $\mathrm{Cl}^{-}$concentrations (Arellano et al. 1999). $\mathrm{Cu}^{2+}$ can compete with $\mathrm{Ca}^{2+}$ for biological ligands (Neiboer and Richardson 1980), producing membrane alterations.

Zinc has been correlated with aneurysm, hypertrophy and hyperplasia in gills and necrosis, leucocitary infiltration and disorganization of parenchyma in liver.

Zinc is an essential element and is a common pollutant. Mining smelting and sewage disposal are major source of zinc pollution. Alvarado et al. (2006) observed in gills of Scophthalmus maximus exposed to $\mathrm{Zn}$ lamellar fusion, hypertrophy and proliferation of chloride cells that produced the thickening of the gill epithelium. Excessive cell proliferation and migration of chloride cells towards the edge of secondary lamellae produced total or partial fusion of the secondary lamellae and a consequent reduction of the distance between adjacent lamellae. The continuous migration of chloride cells to the edge of the secondary lamellae may produce the hyperplasia of this zone leading to a complete fusion of two neighbouring secondary lamellae. Other relevant histopathological alteration observed in S. maximus was the epithelial lifting in the secondary lamellae that is a typical inflammatory reaction against pollutants.

Hemalatha and Banerjee (1997) also observed similar effect of $\mathrm{Zn}$ on gills of Heteropneustes fossilis. The prominent changes in the respiratory organs included periodic deformation of lamellar elements, haemorrhages due to necrosis and sloughing off of the respiratory epithelium, and hyperplasia accompanied by fusion of secondary lamellae. Subsequently, regeneration of the lamellar system from the focal inflammatory tissues takes place. Deposition of glycogen in the muscular layer indicates disturbed aerial respiration.
Fusion of secondary lamellae reduces the surface area for gaseous exchange. The increased thickness of the respiratory epithelium due to uncontrolled hyperplasia of the epithelial cells also increases the diffusion distance between the ambient and vascular components. Vasodilatation in the secondary lamellae of the gills and periodic fluctuations in the mucous cell density are also observed at various stages of $\mathrm{ZnCl}_{2}$ exposure.

The relatively higher zinc concentration in liver of the different fish species may be due to the role of zinc as an activator of numerous enzymes present in the liver.

Loganathan et al. (2006) observed histological alterations in the liver of Labeo rohita at $5 \mathrm{ppm}$ exposure showing severe necrosis, haemorrhage, distended sinusoids with minor vacuolation.

Van Dyk et al. (2007) observed in Oeochromis mossambicus exposed to zinc histological changes in liver including hyalinization, hepatocyte vacuolation, cellular swelling, and congestion of blood vessels.

Other group of pollutants analysed in this study was PAHs. Exposure to crude oil and derivates can induce a variety of toxic symptoms in experimental animals. Some works have also shown structural damage of fish to petroleum derivatives (Khan 1998, 2003).

Only one positive correlation were established, specifically between necrosis hepatic and benzo(a)anthracene concentration in sediments ( $p=0.022, r=0.704)$.

High-molecular-weight aromatic compounds cooccur in the environment, and the benzo[a]pyrene-like compounds are known carcinogens and are associated with development of degenerative, preneoplastic and neoplastic lesions in several fish species (Myers et al. 1994). In contrast, the lower molecular weight hydrocarbons are not primary carcinogens, but may have cytotoxic or other effects which may promote the development of neoplasms (Williams \& Weisburger 1986).

It is interesting to note that PAHs have been shown to be risk factors for hydropic vacuolation in fish (Johnson et al. 1992, 1993). Stehr et al. (1997) also observed in liver of starry flounder a higher risk of developing hydropic vacuolation with increasing concentrations of low-molecular-weight bile FACs (AH). Hydropic vacuolization of bile ductule cells and hepatocytes has been reported from several flatfish species, including European flounder (Moore et al. 1997; Simpson et al. 2000; Stehr et al. 1998; Vethaak and Wester 1996). Its occurrence in certain species has 
been highly associated with exposure to hydrocarbons, and its utility as a histological biomarker for xenobiotic exposure at least for those species is established.

Hepatocytic hypertrophy with microvesicular formation was the most prominent lesion observed in Atlantic cod (Gadus morhua) exposed to wateraccommodated oil fractions containing polycyclic aromatic hydrocarbons (PAHs) and perl date (Mareariscus margarita) sampled at a diesel-fuel contaminated Stillwater pond (Khan 1999).

Stentiford et al. (2003) observed an elevated prevalence of foci of altered hepatocytes (FCA) in the liver of flounder captured from the sites with the highest level of PAH contamination (particularly the Mersey) reinforces earlier reports of this lesion type in flatfish from similar habitats (Becker et al. 1987; Kirby et al. 2000; Köhler 1990; Köhler et al. 1992; Malins et al. 1985; Myers et al. 1987, 1992, 1994; Simpson et al. 2000; Vethaak and Wester 1996).

Delatim Simonato et al. (2008) observed in gills of Prochilodus lineatus exposed to diesel oil epithelial lifting, hyperplasia and aneurysm. The most relevant histological alterations in liver of $P$. lineatus were biliary stagnation and nuclear and cellular degeneration.

An additional complicating factor in the interpretation of data for lesions in the current study is the offshore migration of sole during the spring season. Although experimental evidence has shown that liver neoplasms can be induced by exposure of fish to contaminated sediments (Metcalf et al. 1988; Vethaak et al. 1996), the development of these lesions is thought to occur slowly. Furthermore, it has been suggested that regression and re-modelling of lesions such as hepatocellular FCA, back into normal parenchyma is possible if the stimulating contaminant is removed (Myers et al. 1987). During the offshore period, sole are likely to be exposed to a different array of potential contaminants to those experienced in the home estuary. However, it should be noted that the dab (Limanda limanda), an offshore species of flatfish that is used in national biological effects monitoring programmes in the North Sea, exhibits relatively high prevalence of hepatic alterations (CEFAS 1998), suggesting that contaminant effects will also continue in coastal waters. Consequently, it is likely that any lesions detected in sole provide a sensitive measure of past and current contaminant exposure and are thus extremely useful biomarkers of species, population and ecosystem health.

\section{Conclusions}

In the present study, analysis of major lesion types was performed to quantify the grade of alterations in S. senegalensis from Huelva estuary. Heavy metals presented a higher relationship with histopathological effects than PAHs. Differences on health fish between sampling sites have not been observed being in general the pathological index low for all sites but significant differences were observed between seasons being the prevalence of lesions higher in autumn season due to probably the increase in temperature and decrease in rainfall. In accordance with findings of other similar studies histopathological investigations appear to be valuable tools to detect effects of various aetiologies and contribute to the understanding of the nature of stress responses at lower levels of biological organization.

Acknowledgments This work has been supported by Project SEAPAT: "Biomarkers and histopathology in gilthead seabream, Sparus aurata, and Senegal sole, Solea senegalensis," (CICYT, REN 2003-09361-CO3-03) and by Project SEAMET: "Bioavailability of heavy metals in aquatic ecosystems affected by diffuse pollution" (CICYT, REN 2003-09361-CO3-02, Spain Government). This is the CEIMAR journal publication 15.

\section{References}

Adams SM, Brown AM, Goede RW (1993) A quantitative health assessment index for rapid evaluation of fish condition in the field. T Am Fish Soc 122:63-73

Adams SM, Greeley MS, McHugh Law J, Noga EJ, Zelikoff JT (2003) Application of multiple sublethal stress indicators to assess the health of fish in Pamlico Sound following extensive flooding. Estuaries 26(5):1365-1382

Alazemi BM, Lewis JW, Andrews EB (1996) Gill damage in the freshwater fish Gnathonemus petersii (Family: Mormyridae) exposed to selected pollutants: an ultrastructural study. Environ Technol 17:225-238

Alvarado NE, Quesada I, Hylland K, Marigómez I, Soto M (2006) Quantitative changes in metallothionein expression in target cell-types in the gills of turbot (Scophthalmus maximus) exposed to $\mathrm{Cd}, \mathrm{Cu}, \mathrm{Zn}$ and after a depuration treatment. Aquat Toxicol 77(1):64-77

Arellano JM, Storch V, Sarasquete C (1999) Histological changes and copper accumulation in liver and gills of the Senegal sole, Solea senegalensis. Ecotox Environ Safe 44:62-72

Au DWT (2004) The application of histo-cytopathological biomarkers in marine pollution monitoring: a review. Mar Pollut Bull 48:817-834

Azcue JM (1993) Metales en Sistemas Biológicos: Metales en el medio Ambiente, Ed. PPU, Barcelona 
Bartik M, Piskac A (1981) Veterinary toxicology. Elsevier, Amsterdam, pp 82-89

Becker DS, Ginn TC, Landolt ML, Powell DB (1987) Hepatic lesions in English sole (Parophrys vetulus) from Commencement Bay, Washington, DC. Mar Environ Res 23:153-173

Bernet D, Schmidt H, Meier W, Burkhardt-Holm P, Wahli T (1999) Histopathology in fish: proposal for a protocol to assess aquatic pollution. J Fish Dis 22:25-34

BOJA (1997) num. 27 de 4/3/1997. Orden de 14 de febrero de 1997 , por la que se clasifican las aguas afectadas directamente por vertidos, en desarrollo del Decreto 14/1996, de 16 de enero, por el que se aprueba el Reglamento de calidad de aguas litorales, pp 2591-2598

Bunton TE, Frazier JM (1994) Extrahepatic tissue copper concentrations in white perch with hepatic copper storage. J Fish Biol 45:627-640

Canadian Council of Minister of the Environment (2001) Canadian sediment quality guidelines for the protection of aquatic life: Summary tables. ISBN 1-896997-34-1

CEFAS (1998) Monitoring and surveillance of non-radioactive contaminants in the aquatic environment and activities regulating the disposal of wastes at sea, 1995 and 196. Science Series, Aquatic Environment monitoring Report No. 51. CEFAS, Lowestoft

Chang S, Zdanowicz VS, Murchelano RA (1998) Associations between liver lesions in winter flounder (Pleuronectes americanus) and sediment chemical contaminants from north-east United States estuaries. ICES J Mar Sci 55:954-969

Costa PM, Diniz MS, Caeiro S, Lobo J, Martins M, Ferreira AM, Caetano M, Vale C, DelValls TA, Costa MH (2009) Histological biomarkers in liver and gills of juvenile Solea senegalensis exposed to contaminated estuarine sediments: a weighted indices approach. Aquat Toxicol 92:202-212

Davidson MC, Lorna EW, Ure AM (1999) Effect of sample preparation on the operational speciation of cadmium and lead in freshwater sediment. Fresen J Anal Chem 363: 134-136

De Flora S, Bagnasco M, Zanacchi P (1991) Genotoxic, carcinogenic and teratogenic hazards in the marine environment, with special reference to the Mediterranean Sea. Mutat Res 258:285-320

Delatim Simonato J, Guedes CLB, Martínez CBR (2008) Biochemical, physiological, and histological changes in the neotropical fish Prochilodus lineatus exposed to diesel oil. Ecotox Environ Safe 69:112-120

Dinis MT (1992) Aspects of the potential of Solea senegalensis Kaup for aquaculture: larval rearing and weaning to an artificial diet. Aquacult Fish Manage 23:179-183

Drake PA, Arias M, Rodríguez A (1984) Cultivo extensivo de peces marinos en los esteros de las salinas de San Fernando (Cádiz): II. Características de la producción de peces. Fisheries Research Institute (Spain) (Technical Report) 116:1-23

Farag AM, Boese CJ, Woodward DR, Bergman HL (1994) Physiological changes and tissue metal accumulation in rainbow trout exposed to foodborne and waterborne metals. Environ Toxicol Chem 13:2021-2029

Fernandes C, Fontainhas-Fernandes A, Monteiro SM, Salgado MA (2007) Histopathological gill changes in wild leaping grey mullet (Liza saliens) from the Esmoriz-Paramos coastal lagoon, Portugal. Environ Toxicol, pp 443-448
Fernandes C, Fontainhas-Fernandes A, Ferreira M, Salgado MA (2008) Oxidative stress response in gill and liver of Liza saliens, from the Esmoriz-Paramos coastal lagoon, Portugal. Arch Environ Con Tox 55:262-269

Förstner U, Wittmann GTW (1983) Metal pollution in the aquatic environment, second revised edition. Springer, Berlin

Fowle JR Jr, Abernathy CO, Mass MJ, McKinney JD, North DW, Ohanian EV, Uthus E (1992) Arsenic health research needs. In: Beck BD (ed) Trace substances in environmental health, vol XXV., Gradient CorporationCambridge, Massachusetts, pp 257-271

Froese R, Pauly D (2010) Fishbase. Worl Wide Web Electronic Publication. www.fishbase.org

Fu H, Steinbach OM, Van den Hamer CJA, Balm PHM, Lock RAC (1990) Involvement of cortisol and metallothionein-like proteins in the physiological responses to tilapia (Oreochromis mossambicus) to sublethal cadmium stress. Aquat Toxicol 16:257-270

Gagnon MM, Holdway DA (2000) EROD induction and biliary metabolite excretion following exposure to the water accomodated fraction of crude oil and to chemically dispersed crude oil. Arch Environ Contam Toxicol 38:70-77

Giari L, Manera M, Simoni E, Dezfuli BS (2007) Cellular alterations in different organs of European sea bass Dicentrarchus labrax (L.) exposed to cadmium. Chemosphere 67:1171-1181

Gilderhus PA (1966) Some effects of sublethal concentrations of sodium arsenite on bluegills and the aquatic environment. Trans Am Fish Soc 95:289-296

Gutiérrez M (1967) Coloración histológica para ovarios de peces, crustáceos y moluscos. Investigaciones Pesqueras 31(2): 265-271

Hemalatha S, Banerjee TK (1997) Histopathological analysis of sublethal toxicity of zinc chloride to the respiratory organs of the airbreathing catfish Heteropneustes fossilis (Bloch). Biol Res 30(1):11-21

Hindmarsh JT, McCurdly RF (1986) Clinical and environmental aspects of arsenic toxicity. CRC Crit Rev Clin Lab Sci 23:315-347

Irwin H, van Mouwerick M, Stevens L, Seese M, Bashman W (1997) Environmental contaminants encyclopaedia: lead, cadmium, zinc, mercury and nickel. National Park Service

Jagoe CH, Faivre A, Newman MC (1996) Morphological and morphometric changes in the gills of mosquitofish ( $\mathrm{Gam}$ busia holbrooki) after exposure to mercury (II). Aquat Toxicol 34:163-183

Jimenez-Tenorio N, Morales-Caselles C, Kalman J, Salamanca MJ, González de Canales ML, Sarasquete C, Del Valls TA (2007) Determining sediment quality for regulatory proposes using fish chronic bioassays. Environ Int 33:474-480

Jimenez-Tenorio N, Salamanca MJ, Garcia-Luque E, Gonzalez de Canales ML, Del Valls TA (2008) Chronic bioassay in benthic fish for the assessment of the quality of sediments in different areas of the coast of Spain impacted by acute and chronic oil spills. Environ Toxicol 23(5):634-642

Johnson LL, Stehr CM, Olson OP, Myers MS, McCain BB, Chan SL, Varanasi U (1992) National Status and Trends Program, National Benthic Surveillanc Project, Northeast Coast. Fish histopathology and relationships between lesions and chemical contaminants (1987-1989). NOAA Tech Mem NMFS-NWFC-4 
Kamer TT (1994) Dutch standards for contaminated sediments. Evaluatienota Water 21(250):27-28

Karlsson-Norrgren L, Runn P, Haux C, Forlin L (1985) Cadmium induced changes in gill morphology of zebrafish, Brachydanio rerio (Hamilton-Buchanan), and rainbow trout, Salmo gairdneri. J Fish Biol 27:81-95

Khan RA (1998) Influence of petroleum at a refinery terminal on winter flounder, Pleuronectes americanus. B Environ Contam Tox 61:770-777

Khan RA (1999) Study of pearl date (Margariscus margarita) inhabiting a Stillwater pond contaminated with diesel fuel. B Environ Contam Tox 62:638-645

Khan RA (2003) Health of flatfish from localities in Placentia Bay, Newfoundland, contaminated with petroleum and PCBs. Arch Environ Con Tox 44:485-492

Kirby MF, Lyons BP, Waldock MJ, Woodhead RJ, Goodsir F, Law RJ, Matthiessen P, Neall P, Stewart C, Thain JT, Tylor T, Feist SW (2000) Biomarkers of polycyclic aromatic hydrocarbon $(\mathrm{PAH})$ exposure in fish and their application in marine monitoring. Centre for Environment, Fisheries and Aquaculture Science, Lowestoft, UK. Science Series Technical. Report 110:30

Kotsanis N, Iliopoulou-Georgudaki J (1999) Arsenic induced liver hyperplasia and kidney fibrosis in rainbow trout (Oncorhynchus mykiss) by microinjection technique: a sensitive animal bioassay for environmental metal-toxicity. Bull Environ Contaminat Toxicol 62:169-178

Lanno RP, Hicks B, Hilton JW (1987) Histological observations on intrahepatocytic copper-containing granules in rainbow trout reared on diets containing elevated levels of copper. Aquat Toxicol 10:251-263

Lauren DJ, McDonald DG (1985) Effects of copper on branchial ionoregulation in the rainbow trout, Salmo gairdneri. Richardson J Comp Physiol 13:635-644

Laurent P, Perry SF (1991) Environmental effects on fish gill morphology. Physiol Zool 53:4-25

Loganathan K, Velmurugan B, Hongray Howrelia J, Selvanayagam M, Patnaik B (2006) Zinc induced histological changes in brain and liver of Labeo rohita (Ham.). J Environ Biol 27(1):107-110

Long ER, MacDonald DD, Smith SL, Calder FD (1995) Incidence of adverse biological effects within ranges of chemical concentrations in marine and estuarine sediments. Environ Manage 19:81-87

MacDonald DD, Ingersoll CG, Berger TA (2000) Development and evaluation of consensus-based sediment quality guidelines for freshwater ecosystem. Arch Environ Contam Toxicol 39:20-31

Mallat J (1985) Fish gill structural changes induced by toxicants and other irritants: a statistical review. Can J Fish Aquat Sci 42:630-648

Malins DC, Krahn MM, Brown DW, Rhodes LD, Myers MS, McCain BB, Chan S-L (1985) Toxic chemicals in marine sediment and biota from Mukilteo, Washington: relationships with hepatic neoplasms and other hepatic lesions in English sole (Parophrys vetulus). J Natl Cancer Inst 74: 487-494

Martínez CBR, Nagae MY, Zaia CTBV, Zaia DAM (2004) Acute morphological and physiological effects of lead in the neotropical fish Prochilodus lineatus. Braz J Biol 64(4): 797-807
Matthiessen P, Thain JE, Law RJ, Fileman TW (1993) Attempts to assess the environmental hazard posed by complex mixtures of organic chemicals in UK estuaries. 26:90-95. Mar Pollut Bull 26:90-95 Ontario. Can J Fish Aquat Sci 45:2161-2167

McGeachy SM, Dixon DG (1990) Effect of temperature on the chronic toxicity of arsenate to rainbow trout (Oncorhynchus mykiss). Can J Fish Aquat Sci 47:2228-2234

Metcalf CD, Cairns VW, Fitzsimons JD (1988) Experimental induction of liver tumours in rainbow trout (Salmo gairdneri) by contaminated sediment from Hamilton harbour Ontario. Can J Fish Aquat Sci 45:2161-2167

Moore MJ, Smolowitz RM, Stegeman JJ (1997) Stages of hydropic vacuolation in the liver of winter flounder Pleuronectes americanus from a chemically contaminated site. Dis Aquat Organ 31:19-28

Myers MS, Rhodes LD, McCain BB (1987) Pathologic anatomy and patterns of occurrence of hepatic neoplasms, putative preneoplastic lesions and other idiopathic hepatic conditions in English sole (Parophrys vetulus) from Puget Sound, Washington, USA. J Natl Cancer I 78:333-363

Myers MS, Olson OP, Johnson LL, Stehr CM, Hom T, Varanasi U (1992) Hepatic lesions other than neoplasms in subadult flatfish from Puget Sound, Washington: relationships with indices of contaminant exposure. Mar Environ Res 34:45-51

Myers MS, Stehr CM, Olson OP, Johnson LL, McCain BB, Chan SL, Varanasi U (1994) Relationships between toxicopathic hepatic lesions and exposure to chemical contaminants in English sole (Pleuronectes vetulus), starry flounder (Platichthys stellatus) and white croaker (Genyonemus lineatus) from selected marine sites on the Pacific coast, USA. Environ Health Persp 102:200-215

Neiboer E, Richardson DHS (1980) The replacement of the nondescript term "heavy metals" by a biologically and chemically significant classification of metal ions. Environ Pollut B 1:3-26

NOOA SQuiRTs (Screening Quick Reference Tables). Office of response and restoration: NOAA's National Ocean Service. http://response.restoration.noaa.gov

Okada S, Yamanaka K (1994) Induction of lung-specific DNA damage by methylarsenics via the production free radicals. In: Nriagu JO (ed) Arsenic in the environment, Part II, Human Health and Ecosystem Effects. Wiley, London, pp 143-157

Oliva M, Garrido MC, Sales Márquez D, González de Canales ML (2009) Sublethal and lethal toxicity in juvenile Senegal sole (Solea senegalensis) exposed to copper: a preliminary toxicity range-finding test. Exp Toxicol Pathol 61(2):113-121

Oliveira Ribeiro CA, Belger L, Pelletier E, Rouleau C (2002) Histopathological evidence of inorganic mercury and methylmercury toxicity in the arctic charr (Salvelinus alpinus). Environ Res 83:286-292

Oronsaye JAO (1989) Histological changes in the kidneys and gills of the stickleback, Gasterosteus aculeatus L, exposed to dissolved cadmium in hard water. Ecotox Environ Safe 17:279-290

Part P, Svanberg O, Kiessling A (1985) The availability of cadmium to perfused rainbow trout gills in different water qualities. Water Res 19:427-434

Pedlar RM (2000) The accumulation, distribution and toxicological effects of arsenic in lake whitefish (Coregonus 
clupeaformis) and lake trout (Salvelinus namacycush) exposed by the dietary route of uptake. M. Sc. Thesis. Department of Zoology, University of Manitoba. Winnipeg, Manitoba, p 150

Pedlar RM, Ptashynski MD, Evans R, Klaverkamp JF (2002) Toxicological effects of dietary arsenic exposure in lake whitefish (Coregonus clupeaformis). Aquat Toxicol 57: 167-189

Pratap HB, Wendelaar Bonga SE (1993) Effect of ambient and dietary cadmium on pavement cells, chloride cells and $\mathrm{Na}^{+} / \mathrm{K}^{+}$-ATPase activity in the gills of the freshwater teleost Oreochromis mossambicus at normal and high calcium levels in the ambient water. Aquat Toxicol 26:133-150

Randi AS, Monserrat JM, Rodríguez EM, Romano LA (1996) Histopathological effects of cadmium on the gills of the freshwater fish, Macropsobrycon uruguayanae Eigenmann (Pisces, Atherinidae). J Fish Dis 19:311-322

Rankin MG, Dixon DG (1994) Acute and chronic toxicity of waterborne arsenite to rainbow trout (Oncorhynchus mykiss). Can J Fish Aquat Sci 51:372-380

Reid SD, McDonald DG (1991) Metal binding activity of the gills of rainbow trout (Oncohrynchus mykiss). Can J Fish Aquat Sci 48:1061-1068

Robbins SL, Cotran RS (1984) Patología Estructural y Funcional. Intramericana, Madrid, pp 226-228

Roncero V, Vincente JA, Redondo E, Gãzquez A, Duran E (1990) Experimental lead nitrate poisoning: microscopic and ultrastructural study of the gills of tench (Tinca tinca, L.). Environ Health Perspet 89:137-144

Roncero V, Durán E, Soler F, Masot J, Gómez L (1992) Morphometric, structural and ultrastructural studies of tench (Tinca tinca L.) hepatocytes after copper sulphate administration. Environ Res 57:45-58

Roy LA, Steinert S, Bay SM, Greenstein D, Sapozhnikova Y, Bawardi O, Leifer I, Schlenk D (2003) Biochemical effects of petroleum exposure in hornyhead turbot (Pleuronichthys verticalis) exposed to a gradient of sediments collected from a natural petroleum seep in CA, USA. Aquat Toxicol 65:159-169

Sarasquete C, González de Canales ML, Arellano JM, MuñozCueto JA, Ribeiro L, Dinis MT (1998) Histochemical study of skin and gills of Senegal sole, Solea senegalensis larvae and adults. Histo Histopathol 13:727-735

Schwaiger J, Wanke R, Adam S, Pawert M, Honnen W, Triebskorn R (1997) The use of histoapthological indicators to evaluate contaminant-related stress in fish. J Aquat Ecosyst Stress Recovery 6:75-86

Shaw JR, Gabor K, Hand E, Lankowski A, Durant L, Thigodeau R, Stanton C, Barnaby R, Coutermarsh B, Karlson K, Sato D, Hamilton JW, Stanton BA (2007) Role of glucocorticoid receptors in acclimation of killfish (Fundulus heteroclitus) to seawater and effects of arsenic. Am J Physiol 292:1052-1060

Shiomi K, Sugiyama Y, Shimakura K, Nagashima Y (1996) Retention and biotransformation of arsenic compounds administered intraperitoneally to carp. Fish Sci 62:262-266

Simpson MG, Parry M, Kleinkauf D, Swarbreck D, Walker P, Leah RT (2000) Pathology of the liver, kidney and gonad of flounder (Platichthys flesus) from a UK estuary impacted by endocrine disrupting chemicals. Mar Environ Res 50:283-287
Sorenson EMB (1991) Arsenic. In: Sorenson EMB (ed) Metal poisoning in fish. CRC Press, London, pp 61-99

Sorenson EMB, Ramírez-Mitchell R, Harlan CW, Bell JS (1980) Cytological changes in fish liver following chronic, environmental arsenic exposure. Bull Environ Contaminat Toxicol 25:93-99

Spies RB, Davis PH, Stuerner DH (1980) Ecology of a petroleum seep off the California coast. In: Geyer R (ed) Marine environmental pollution. Elsevier, Amsterdam, pp 229-263

Stehr CM, Myers MS, Burrows D, Krahn MM, Meador J, McCain BB, Varanasi U (1997) Chemical contamination and associated liver diseases in two species of fish from San Francisco Bay and Bodega Bay. Ecotoxicology 6:35-65

Stehr CM, Johnson LL, Myers MS (1998) Hydropic vacuolation in the liver of three species of fish from the U.S. West Coast: lesion description and risk assessment associated with contaminant exposure. Dis Aquat Organ 32:119-135

Stentiford GD, Longshaw M, Lyons BP, Jones G, Green M, Feist SW (2003) Histopathological biomarkers in estuarine fish species for the assessment of biological effects of contaminants. Mar Environ Res 55:137-159

Styblo M, Del Razo LM, LeCluyse EL, Hamilton GA, Wang C, Cullen WR, Thomas DJ (1999) Metabolism of arsenic in primary cultures of human and rat hepatocytes. Chem Res Toxicol 12:560-565

The SJ, Adams SM, Hinton DE (1997) Histopathological biomarkers in feral freshwater fish populations exposed to different types of contaminant stress. Aquat Toxicol 37:51-70

Thophon S, Kruatrachue M, Upatham ES, Pokethitiyook P, Ssahaphong S, Jaritkhuan S (2003) Histopathological alterations of white seabass, Lates calcarifer, in acute and subchronic cadmium exposure. Environ Pollut 121:307-320

USEPA (United States Environmental Protection Agency) (2002) National Recommended Water Quality Criteria. EPA-822-R-02-047, Office of Science and Technology

Usha Rani A (1986) Effect of cadmium on some aspects of physiology and histology in the edible freshwater teleost, Tilapia mossambica (Peters). Thesis. Sri Venkateswara University, Tirupati

Usha Rani A, Ramamurthi R (1989) Histopathological alterations in the liver of freshwater teleost tilapia mossambica in response to cadmium toxicity. Ecotox Environ Safe 17:221-226

Van Dyk JC, Pieterse GM, Van Vuren JHJ (2007) Histological changes in the liver of Oreochromis mossambicus (Cichlidae) after exposure to cadmium and zinc. Ecotox Environ Safe 66(3):432-440

Verbost PM, Flik G, Lock RAC, Wendelaar Bonga SE (1987) Cadmium inhibition of $\mathrm{Ca}^{2+}$ uptake in rainbow trout gills. Am J Physiol 253:216-221

Verbost PM, Van Rooij J, Flik G, Lock RAC, Wendelaar Bonga SE (1989) The movement of cadmium through freshwater trout branchial epithelium and its interference with calcium transport. J Exp Biol 145:185-197

Vethaak AD, Wester PW (1996) Diseases of flounder Platichthys flesus in Dutch coastal and estuarine waters, with particular reference to environmental stress factors. II. Liver histopathology. Dis Aquat Org 26:99-116

Vethaak AD, Jol JG, Meijboom A, Eggens ML, Rheinhalt T, Wester PW, Van de Zande T, Bergman A, Dankers N, Ariese F, Baan RA, Everts JM, Opperhuizen A, Marquenie JM (1996) Skin and liver diseases induced in flounder (Platichthys flesus) 
after long-term exposure to contaminated sediments in largescale mesocosms. Environ Health Perspect 104:1218-1229

Vicente Martorell JJ, Galindo-Riaño MD, García-Vargas M, Castro-Granado D (2009) Bioavailability of heavy metals monitoring water, sediments and fish species from a polluted estuary. J Hazard Mater 162:823-836

Wangsongsak A, Utarnpongsa S, Kruatrachue M, Ponglikitmongkol M, Pokethitiyook P, Sumranwanich T (2007) Alterations of organ histopathology and metallothionein mRNA expression in silver barb, Puntius gonionotus during subchronic cadmium exposure. J Environ Sci 19:1341-1348
Wicklund-Glynn A, Norrgren L, Mussener A (1994) Differences in uptake of inorganic mercury and cadmium in the gills of the zebrafish, Brachydanio rerio. Aquat Toxicol 30:13-26

Williams GM, Weisburger JH (1986) Chemical carcinogens. In: Klaassen CD, Amdur MO, Doull J (eds) Casarett and Dloull's toxicology. Macmillan, New York, pp 99-173

Yamauchi H, Fowler BA (1994) Toxicity and metabolism o inorganic and methylated arsenicals. In: Nriagu JO (ed) Arsenic in the environment, Part II: Human health and ecosystem effects. Wiley, London, pp 35-91 